\title{
SOVIETINĖS REPRESIJOS PRIEŠ LIETUVOS KARIUOMENĖS KARININKUS
}

\author{
Ats. plk. Andrius Tekorius \\ Generolo Jono Žemaičio Lietuvos karo akademija
}

Anotacija. Straipsnyje atskleistos sovietiniu represiju prieš Lietuvos kariuomenès karininkus priežastys, pobūdis ir mastas, pateikti duomenys apie represuotus Lietuvos krašto apsaugos ministrus ir karininkus.

Pagrindiniai žodžiai: sovietinè okupacija, Lietuvos kariuomené, Lietuvos kariuomenès karininkai, sovietinès represijos, šnipinèjimas, represuoti Lietuvos karininkai ir krašto apsaugos ministrai.

\section{IVADAS}

Sovietinès okupacijos metais represijas patyrè didžioji mūsų tautos dalis. Okupantų buvo suimti, kalinti ir ištremti tūkstančiai Lietuvos gyventojų. Sovietinių represijų neišvenge ir Lietuvos karininkija. Ji tapo vienu pirmųjų sovietinių okupantų taikinių.

Lietuvos karininkų ${ }^{1}$ sovietinių represijų tema Lietuvos istoriografijoje nèra nauja. Šią temą ịvairiais aspektais yra nagrinejję ir tyrimų rezultatus skelbę Arvydas Anušauskas, Teresė Birutė Burauskaitė, Jonas Dobrovolskas, Stasys Knezys, Aras Lukšas, Algirdas Markūnas, Antanas Martinionis, Jonas Rudokas, Vytautas Jasulaitis, Gintautas Surgailis, Romualdas Svidinskas, Antanas Tyla, Vytautas Zabielskas, Dalius Žygelis ir kiti. Sovietiniuose kalejimuose ir lageriuose (priverčiamojo darbo stovyklose) patirti išgyvenimai aprašyti Lietuvos kariuomenès karininkų Viktoro Ašmensko, Antano Martinionio, Juozo Palukaičio, Jono Petruičio

1 Šiame straipsnyje Lietuvos karininkai skirstomi $\mathfrak{i}$ tikrosios tarnybos karininkus, tarnavusius Lietuvos kariuomeneje iki jos likvidavimo 1941 metais, ir atsargos karininkus, išleistus ị atsargą iki Lietuvos okupacijos $1940 \mathrm{~m}$. birželio $15 \mathrm{~d}$. 
ir Simo Stanaičio atsiminimuose. Savo darbus šia tema yra publikavę ir žurnalistai, besirūpinantys žuvusiųjų ir nukentejjusių nuo sovietinių represijų atminimo išsaugojimu. Tačiau dar trūksta išsamių tyrimų šia skaudžia Lietuvai ir jos kariuomenei tema.

Terminas „represijos“ reiškia prievartos priemonių naudojimą atskirų asmenų ar žmonių grupių atžvilgiu ${ }^{2,3}$. Ir tai ne tik visiems suprantamas kalinimas, trèmimas ar žmogaus teisių ribojimas. Sovietiniai okupantai žude šaudydami, kankindami per tardymus, pasmerkdami lètai mirčiai kalinamus nežmoniškai sunkiomis sąlygomis kalejimuose ir darbo stovyklose - marindami badu, versdami dirbti nepakeliamai sunkius darbus miškuose, kasyklose ir gamyklose, kęsti šaltị ar alinantị karštị, nesuteikdami reikiamos medicininès pagalbos. Todèl šimtai suimtųjų žuvo ne tik šaudymo kamerose nuo okupantų paleistų kulkų, bet ir nuo tardytojų sužalojimų, nuo visiško išsekimo, šalčio, bado ir ligų kalejjimuose ir lageriuose. Ne ką lengvesnemis sąlygomis teko gyventi ir tremtiniams - jiems taip pat teko kęsti badą ir šaltị atšiauriuose Sovietų Sąjungos regionuose, dirbti miškuose ir gamyklose.

Prie represinių prievartos priemonių priskirtinas ir atleidimas iš darbo ar tarnybos, kai liekama be pragyvenimo šaltinio, turto konfiskavimas, šeimų trèmimas, persekiojimas po kalinimo ar tremties - draudimas grịžti ị Lietuvą, prisiregistruoti ir gyventi norimoje vietoje, dirbti pagal igytą išsilavinimą ar turimą profesiją.

Prie represijų taip pat priskirtina ir priverstine emigracija ł̇ užsienio šalis, siekiant išsaugoti savo ir artimųjų gyvybę. Pasitraukusieji i Vakarus prarado turtą, artimuosius, galimybę gyventi ir mirti savo Tẻvynejje.

Labiausiai sovietinio režimo buvo persekiojami aukšti valstybės tarnautojai, politinių ir visuomeninių organizacijų vadovai ir aktyvūs nariai, Lietuvos kariuomenès karininkai, karinès žvalgybos ir saugumo, įvairių policijos rūšių pareigūnai, mokytojai ir šauliai.

Nuo sovietinių represijų žiauriai nukentejo ir jų šeimos - jos buvo ištremtos ị Sovietų Sąjungos atšiaurius, dažnai negyvenamus Komijos, Kazachstano, Altajaus, Jakutijos ir kitus Sibiro rajonus. Daugelis jų ten ir žuvo nuo šalčio, ligų ir bado.

2 Didysis lietuvių kalbos žodynas. Represija <lot. represio - nuslopinimas, numalšinimas> - teis. bausmé, baudžiamoji priemonè.

3 Vaitkevičiūtè V., Tarptautinių žodžių žodynas, Vilnius, 2004, p. 908. 
Iš 100 prieškario Lietuvos Respublikos vyriausybių narių 44 (44 proc.) patyrè sovietines represijas ${ }^{4} .16$ iš jų buvo sušaudyti, tarp jų 2 ministrai pirmininkai - prof. Pranas Dovydaitis ir Vytautas Petrulis; 6 vidaus reikalų ministrai - Petras Aravičius, ats. brg. gen. Julius Čaplikas, Antanas Endziulaitis, ats. plk. Steponas Rusteika, ats. brg. gen. Kazys Skučas ir Zigmas Starkus; 2 krašto apsaugos ministrai - ats. plk. Balys Giedraitis ir ats. plk. ltn. Juozas Papečkys; 2 švietimo ministrai - Kazys Bizauskas ir Kazys Jokantas, finansų ministras ats. div. gen. Jonas Sutkus, susisiekimo ministras ats. ltn. Jonas Masiliūnas, teisingumo ministras Antanas Tamošaitis ir užsienio reikalų ministras Valdemaras Vytautas Čarneckis. 9 Lietuvos Respublikos vyriausybių nariai žuvo kalejjimuose ir lageriuose, 3 mire tremtyje, 11 grịžo iš lagerių ar tremties, 5 buvo kalinti pirmosios sovietinès okupacijos laikotarpiu, išlaisvinti 1941 m. per Birželio sukilimą. Represuotų ministrų šeimos ištremtos ị Komijos ASSR, Altajaus kraštą, Tomsko ir Novosibirsko sritis, ị Jakutijos ASSR šiaurę prie Laptevų jūros. 34 ministrai, siekdami išvengti susidorojimo, pasirinko priverstinę emigraciją ${ }^{5}$.

Iš 16 Lietuvos krašto apsaugos ministrų 9 (56,2 proc.) buvo represuoti, 2 iš jų sušaudyti - ats. plk. Balys Giedraitis ${ }^{6}$ ir ats. plk. ltn. Juozas Papečkys ${ }^{7}$; 3 žuvo kalejimuose ir lageriuose ar mire tremtyje - ats. gen. ltn. Pranas Liatukas $^{8}$, ats. plk. ltn. Antanas Merkys ${ }^{9}$ ir prof. Augustinas Voldema-

4 Banevičius A., 111 Lietuvos valstybès 1918-1940 politikos veikèjų. Enciklopedinis žinynas, Vilnius, 1991, p. 35-163.

5 Sušaudytos ir nukankintos Lietuvos vyriausybės, http://genocid.lt/centras/lt/3002/a/

6 Plk. Balys Giedraitis suimtas 1940-11-10, po dviejų savaičių tardymo paleistas, 1941 m. sausio pradžioje vèl suimtas, kalintas Kaune, sušaudytas 1941-06-26 Červenèje (Baltarusija).

7 Plk. ltn. Juozas Papečkys suimtas 1941-06-14, kalintas Gario lageryje Sevurallage, sušaudytas 1942-11-04 Sverdlovsko NKVD vidaus kalèjime.

8 Gen. ltn. Pranas Liatukas dalyvavo Lietuvos laisvès armijos veikloje. 1945 m. suimtas, kalintas Kauno ir Vilniaus kalejimuose. Mirè 1945 m. Vilniaus Lukiškių kalèjime.

9 Plk. ltn. Antanas Merkys suimtas 1940-07-09 Rygoje, kalintas Kirovo, Ivanovo, Butyrkų kalèjimuose. 1952 m. nuteistas 25 m. Iš kalèjimo paleistas 1954 m. Mirẻ 1955 m. Vladimiro invalidų namuose. 
$\operatorname{ras}^{10} ; 2$ po kalinimo grịžo ị Lietuvą - ats. gen. ltn. Mykolas Velykis ${ }^{11}$ ir Leonas Bistras $^{12} ; 2$ išlaisvinti iš kalèjimo prasidejjus Vokietijos-Sovietų Sąungos karui - ats. gen. ltn. Teodoras Daukantas ${ }^{13}$ ir ats. gen. ltn. Petras Šniukšta ${ }^{14}$.

Sovietinių okupantų represijų nepaliestas liko tik vienas buvęs krašto apsaugos ministras - prof. Jonas Šimkus ${ }^{15}$.

Nuo sovietinių represijų i Vakarus pasitraukė 6 buvę krašto apsaugos ministrai - ats. brg. gen. prof. Stasys Dirmantas ${ }^{16}$, brg. gen. Kazys Musteikis ${ }^{17}$, ats. plk. ltn. Balys Sližys ${ }^{18}$, ats. plk. ltn. Jonas Variakojis ${ }^{19}$, ats. plk. ltn. Povilas Žadeikis ${ }^{20}$ ir ats. plk. Konstantinas Žukas ${ }^{21}$.

Viena didžiausių sovietines represijas patyrusių visuomenės grupių Lietuvos karininkija. Ir tam yra keletas priežasčių. Visų pirma Lietuvos karininkija sovietinių okupantų buvo naikinama ir persekiojama kaip išsilavinusi, profesionaliai parengta, patriotiška, labai motyvuota ir organizuota jèga, galinti organizuoti ginkluotą pasipriešinimą sovietinei okupacijai ir aneksijai. Represijomis buvo siekiama palaužti galimą pasipriešinimą pašalinant patriotiškai nusiteikusius karininkus iš kariuomenès,

10 Augustinas Voldemaras suimtas 1940-06-19, kalintas Maskvos Lubiankos kalëjime, mirè 1942-12-16 Maskvos Butyrkų kalëjime.

11 Gen. ltn. Mykolas Velykis suimtas 1944 m., kalintas Kauno kalejime, Vilniaus Rasų, Macikų, Archangelsko, Karagandos lageriuose. Paleistas 1954 m. Mire 1955 m. Vilniuje.

12 Leonas Bistras suimtas 1940-07-12, kalintas Kauno kalëjime, lageryje Šiaurès Pečioroje. Paleistas $1954 \mathrm{~m}$. Mirè $1971 \mathrm{~m}$. Kaune.

13 Gen. ltn. Teodoras Daukantas suimtas 1940 m., kalintas Kaune, išlaisvintas prasidejus karui, 1944 m. pasitraukè ị Vokietiją, mirè 1960 m. Argentinoje.

14 Gen. ltn. Petras Šniukšta suimtas 1940 m., išlaisvintas prasidejus karui, dirbo kerdžiumi Šilutès r., mire 1952 m. Lietuvoje.

15 Prof. Jonas Šimkus mirè 1944 m. Kauno apskrityje.

16 Brg. gen. prof. Stasys Dirmantas 1944 m. pasitraukè i Vokietiją. Miré 1975 m. JAV.

17 Brg. gen. Kazys Musteikis 1940 m. su prezidentu Antanu Smetona pasitraukè i Vokietiją. Mirè 1977 m. JAV.

18 Plk. ltn. Balys Sližys 1944 m. pasitraukè ị Vokietiją. Mirè 1957 m. JAV.

19 Plk. Itn. Jonas Variakojis 1944 m. pasitraukè ị Vokietiją. Mire 1963 m. JAV.

${ }^{20}$ Plk. ltn. Povilas Žadeikis 1923-1940 m. dirbo Lietuvos konsulu Čikagoje, generaliniu konsulu Niujorke, nepaprastuoju pasiuntiniu ir igaliotuoju ministru Vašingtone. Mirè 1957 m. JAV.

21 Plk. Konstantinas Žukas 1944 m. pasitraukè ị Vokietiją. Mirè 1962 m. JAV. 
juos fiziškai sunaikinant, ịkalinant ar išremiant $\mathfrak{i}$ atšiauriausius Sovietų Sąungos rajonus. Ryžtą ginti savo kraštą Lietuvos karininkai jau įrode kovose su bolševikais Lietuvos nepriklausomybės kovų metu, ir sovietiniai okupantai to nepamiršo.

Dèl Lietuvos karininkų keliamos grèsmès okupaciniam režimui sovietinè valdžia neklydo. Dešimtys Lietuvos karininkų aktyviai dalyvavo Birželio sukilime, kovoti su bolševikais stojo ị savisaugos batalionus, Vietinę rinktinę, Tẻvynès apsaugos rinktinę, sumaniai vadovavo partizanų daliniams, dalyvavo neginkluotame antisovietiniame pasipriešinime, būdami emigracijoje aktyviai rūpinosi „Lietuvos byla“.

Kartu su tikrosios karo tarnybos karininkais sovietų buvo represuoti ir Lietuvos kariuomenès atsargos karininkai, Karo mokyklos aspirantai aktyvūs, patriotiški valstybès tarnautojai, politinių ir visuomeninių organizacijų nariai, Šaulių sąjungos padalinių vadai, ịvairių pasipriešinimo okupantams organizacijų nariai.

Tiesiogines sovietų represijas patyrè 1262 Lietuvos kariuomenès karininkai. 150 iš jų okupantų buvo sušaudyti, 663 žuvo kalejjimuose ir lageriuose ar mirè tremtyje. Per 2000 karininkų pasirinko priverstinę emigraciją ${ }^{22}$.

Sovietų buvo represuotas 21 Lietuvos generolas $(38,8$ proc. visu prieškario generolų). 6 iš jų buvo sušaudyti - ats. brg. gen. Julius Čaplikas, brg. gen. Antanas Gustaitis, ats. gen. Itn. Petras Kubiliūnas, ats. gen. ltn. Kazys Ladiga, ats. brg. gen. Kazys Skučas ir ats. div. gen. Jonas Sutkus, 5 žuvo kalejimuose ir lageriuose - ats. gen. ltn. Juozas Barzda-Bradauskas, ats. div. gen. Zenonas Gerulaitis, ats. gen. ltn. Pranas Liatukas, brg. gen. Jonas Juodišius, ats. div. gen. Kazys Sprangauskas ir ats. gen. ltn. Vytautas Stomma. Nuo sovietinių represijų i Vakarus buvo priversti pasitraukti 10 generolų.

\footnotetext{
22 Markūnas A., Lietuvos kariuomenès karininkai priverstinėje emigracijoje Vokietijoje 1944-1949 m., Kaunas, 2008, p. 6-34.
} 


\section{LIETUVOS OKUPACIJA}

Sovietų Sąungos politinė valdžia, žvalgybos ir saugumo tarnybos Baltijos šalių okupacijai ruošèsi iš anksto. Dar nuo 1935 metų buvo tikslingai renkama informacija apie Lietuvos kariuomenę, karinę žvalgybą ir kontržvalgybą, Valstybès saugumo departamentą, šalies vidaus ir užsienio politiką $^{23}$, buvo identifikuoti aktyviausi ir ịtakingiausi asmenys, galèję pasipriešinti Sovietų Sąjungos planuotai šalies okupacijai ir aneksijai.

1939 m. spalio 11 d. SSRS vidaus reikalų liaudies komisaro Lavrentijaus Berijos pasirašytame ịsakyme Nr. 001223 buvo suformuluotos represinės politikos nuostatos numatytų aneksuoti Baltijos šalių atžvilgiu, nurodytos persekiotinų ir sunaikintinų asmenų ir organizacijų kategorijos. I jas buvo ịtraukti ịvairių politinių partinių ir visuomeninių organizacijų nariai, valstybinių ìstaigų darbuotojai, karininkai, kalejjimų tarnautojai, policininkai, teisejjai, prokurorai, teismo tardytojai, dvarininkai, stambūs verslininkai ir kiti. Visi jie turejo būti suregistruoti ir okupavus Baltijos šalis represuoti pagal Sovietų Sąjungos baudžiamojo kodekso 58 straipsnị ${ }^{24}$.

1940 m. birželio 15-ąją Sovietų Sąjungai okupavus Lietuvą, buvo pradètas vykdyti stalininis planas - inkorporuoti nepriklausomą valstybę i „broliškų respublikų šeimą“. Jau 1940 m. rugpjūčio 3 d., nepraèjus ir dviem mėnesiams nuo okupacijos pradžios, Lietuva tapo Sovietų Sąjungos respublika.

Jau pirmomis okupacijos dienomis buvo pradèta suiminèti Lietuvos kariuomenès karininkus, valdininkus, politikus, visuomenès veikèjus.

Pirmosiomis aukomis tapo vidaus reikalų ministras ats. brg. gen. Kazys Skučas ir Valstybès saugumo departamento direktorius Augustinas Povilaitis. Tenkinant 1940 m. birželio 14 d. Sovietų Sąjungos ultimatumo Lietuvai reikalavimus, jie $1940 \mathrm{~m}$. birželio $15 \mathrm{~d}$. buvo suimti pasienyje su Vokietija, kalinti Kauno komendantūros Karo kalejime, įkurtame VI forte, vèliau Kauno sunkiųjų darbų kalèjime. 1940 m. liepos 23 d. ats. brg. gen. Kazys Skučas ir Augustinas Povilaitis buvo išvežti tardyti i Maskvą ir 1941 m. liepos mèn. sušaudyti Butyrkų kalèjime.

\footnotetext{
23 Anušauskas A., Teroras. 1940-1958 m. Vilnius, 2012, p. 15.

24 Anušauskas A., Sovietinis genocidas ir jo padariniai, http://genocid.lt/GRTD/Tremtis/ arvydas1.htm
} 
Okupantai perèmé valstybės institucijų, politinių partijų ir visuomeninių organizacijų archyvus, karininkų tarnybos, apdovanojimų lapus, atestacijos ir kitus dokumentus, padedami vietinių komunistų sudarinejo represuotinų asmenų sąrašus, nustatinèjo jų buvimo vietą, rinko „nusikalstamos" veiklos įrodymus.

Nors iki 1940 m. liepos 1 d. dar tebedirbo Lietuvos parlamentas Seimas, okupantų statytiniai, remiami okupacinès kariuomenès, per pirmąsias dvi okupacijos savaites suėmé 87 piliečius, apkaltinę juos kontrrevoliucine veikla pagal dar oficialiai Lietuvoje negaliojančio RSFSR baudžiamojo kodekso 58 str. $^{25}$

Likus dešimčiai dienų iki masinių suėmimų pradžios, $1940 \mathrm{~m}$. liepos 1 d. „Lietuvos aide“ išspausdintame straipsnyje „Krašto demokratizacija“ buvo paskelbti okupantų ir jų statytinių tikslai: „Krašto demokratizacija - tai kova be pasigailejjimo su visais liaudies priešais $<\ldots$. . Sutriuškintos reakcijos pakalikai dar ne visai išvaryti iš valstybės aparato. Jų dar yra ir kariuomeneje.... ${ }^{26}$

Liepos mėnesị, prieš rinkimus ị naujajị Liaudies seimą, kuris pagal Maskvos scenarijų turejjo paskelbti sovietų valdžią Lietuvoje ir pareikšti lietuvių tautos „valią“ tapti viena iš SSRS respublikų, prasidèjo masiniai areštai, vykdomi pagal Antano Sniečkaus 1940 m. liepos 7 d. patvirtintą "liaudies priešų“ operatyvinio likvidavimo planą. Daugumą suimtųjų sudarè karininkai, valstybès tarnautojai, mokytojai, priklausę ìvairioms politinėms ir visuomeninèms organizacijoms ${ }^{27}$.

Rengiantis suėmimams vien Kauno kalejjime buvo numatyta 200 vietų naujiems kaliniams. Siekiant atlaisvinti vietą, iš septynių Lietuvos kalejimų buvo paleisti 525 kriminaliniai nusikaltèliai. Kai kurie iš jų tapo NKVD kalèjimų prižiūrètojais (priimti nepaisant kriminalinės praeities) ir uoliai tarnavo naujajai valdžiai ${ }^{28}$.

1940 m. liepos 11-17 d. buvo suimti 504 žmonès. Tarp jų - buvęs

25 Burauskaitė T. B., 12-asis kilometras: 1942-1943 m. Sverdlovske sušaudyti Lietuvos piliečiai. Vilnius, 2015, p. 2.

26 Anušauskas A., Sovietinis genocidas ir jo padariniai, http:/genocid.lt/GRTD/Tremtis/ arvydas1.htm

27 Burauskaitė T. B., 12-asis kilometras: 1942-1943 m. Sverdlovske sušaudyti Lietuvos piliečiai. Vilnius, 2015, p. 2.

28 Anušauskas A., Sovietinis genocidas ir jo padariniai, http:/genocid.lt/GRTD/Tremtis/ arvydas1.htm 
ministras pirmininkas ir švietimo ministras Leonas Bistras, buvęs žemės ūkio ministras Jonas Aleksa, Tautininkų sąjungos pirmininkas Dominykas Cesevičius, buvę vidaus reikalų ministrai ats. brg. gen. Julius Čaplikas, ats. plk. Silvestras Leonas ${ }^{29}$, ats. plk. Steponas Rusteika, Policijos departamento direktorius Jonas Statkus, Kariuomenès prokuroras brg. gen. Emilis Vimeris, Šaulių sąjungos vadas plk. Pranas Saladžius ${ }^{30}$, Kariuomenès štabo II (žvalgybos) skyriaus viršininkas gen. št. plk. Kostas Dulksnys, II skyriaus viršininko pavaduotojas plk. ltn. Juozas Matusaitis, II skyriaus Žvalgybos ir kontržvalgybos dalies vedejjas plk. ltn. Petras Kirlys, Kariuomenès Ginklavimo valdybos Bendrojo skyriaus viršininkas plk. Mykolas Kalmantas ir daugelis kitų.

Jau liepos 23 d. ị Maskvą buvo išgabenta 11 kalinių - buvę vidaus reikalų ministrai brg. gen. Kazys Skučas ir brg. gen. Julius Čaplikas, Valstybès saugumo departamento direktorius Augustinas Povilaitis, Policijos departamento direktorius Jonas Statkus, karinės žvalgybos karininkai gen. št. plk. Kostas Dulksnys, plk. ltn. Juozas Matusaitis, plk. ltn. Petras Kirlys ir kiti.

Suèmimai Lietuvoje vyko visą pirmosios okupacijos laikotarpi - nuo 1940 m. birželio 15 d. iki 1941 m. birželio 28 d., tačiau intensyviausiai dviem suèmimų bangomis - 1940 m. liepos-rugpjūčio mèn. ir $1941 \mathrm{~m}$. sausio mèn.

Suimtieji buvo kalinami Kaune - VSD ${ }^{31}$ (vèliau reorganizuoto $\mathfrak{i}$ LSSR NKVD ${ }^{32}$ ) vidaus kalejjime, Kauno sunkiųjų darbų kalejjime (vèliau - NKVD kalejimas Nr.1), Kauno tvirtovès VI, IX fortuose; Vilniuje - NKVD Vilniaus valdybos vidaus kalejjime, Lukiškių kalejime, taip pat Šiaulių, Panevėžio, Telšių, Marijampolès, Raseinių kalejjimuose.

Iki Vokietijos-Sovietų Sąungos karo pradžios Lietuvoje buvo suimti ir kalinami 6606 asmenys. 3434 asmenys jau buvo nuteisti NKVD Ypatingojo pasitarimo ir išvežti ị Komijos ASSR, Karelijos SSR ir Archangels-

\footnotetext{
29 Vidaus reikalų ministras, Vyriausiojo tribunolo teisèjas. Iš kalejimo išlaisvintas Birželio sukilimo metu.

30 Iš kalèjimo išlaisvintas Birželio sukilimo metu.

31 VSD - Valstybès saugumo departamentas.

32 NKVD (rus. k. Народный комиссариат внутренних дел - Vidaus reikalų liaudies komisariatas) - Sovietų Sąungos saugumo institucija.
} 
ko srities lagerius, Gorkio, Sol Ilecko kalejjimus ${ }^{33}$.

Masinio trėmimo metu $1941 \mathrm{~m}$. birželio 14-18 d. buvo suimta ir išvežta ị lagerius 3915 asmenų, daugiausia nuo tremiamų šeimų atskirtų vyrų. Didžioji jų dalis - 2425 asmenys - ikalinti Rešotų ir Norilsko lageriuose Krasnojarsko krašte, 387 - Sevurallage, Sverdlovsko srityje. Likusieji kalejjo Kazachijos SSR, Molotovo ${ }^{34}$ ir Vologdos sričių lageriuose ${ }^{35}$.

Iš viso pirmosios sovietinès okupacijos metais kalejjimuose ir GULAG $^{36}$ lageriuose atsidūrè 7349 Lietuvos piliečiai ${ }^{37}$.

\section{LIETUVOS KARIUOMENĖS LIKVIDAVIMAS IR KARININKŲ ŠALINIMAS IŠ KARIUOMENĖS}

Nuo pat pirmos Lietuvos okupacijos dienos imta sovietinti visas svarbiausias valstybès institucijas. Ypatingas dèmesys skirtas kariuomenei. Siekiant palaužti galimą ginkluotą pasipriešinimą, imta sparčiai reorganizuoti Lietuvos kariuomenę, šalinti iš jos sovietų okupantams pavojingus karininkus.

Kariuomenę tuo metu sudarè Kariuomenès štabas, Aukštoji karo mokykla, Karo mokykla, trys pėstininkų divizijos (devyni pėstininkų ir keturi artilerijos pulkai bei penkios priešlèktuvinès motorizuotosios kuopos), taip pat ginklų rūšys - kavalerija, karo aviacija, karo technikos dalys ir priešlèktuvinès apsaugos rinktinè, kariuomenès aprūpinimo padaliniai ${ }^{38}$.

1940 m. birželio 1 d. Lietuvos kariuomenèje buvo 28005 žmonès -

33 Burauskaitė T. B., 12-asis kilometras: 1942-1943 m. Sverdlovske sušaudyti Lietuvos piliečiai. Vilnius, 2015, p. 2.

34 Nuo 1957 m. Permès sritis.

35 Burauskaitè T. B., 12-asis kilometras: 1942-1943 m. Sverdlovske sušaudyti Lietuvos piliečiai. Vilnius, 2015, p. 2.

36 GULAG (rus. k. Glavnoje upravlenije lagerej NKVD - NKVD vyriausioji lagerių valdyba). GULAG buvo pavaldūs lageriai.

37 Burauskaitè T. B., 12-asis kilometras: 1942-1943 m. Sverdlovske sušaudyti Lietuvos piliečiai. Vilnius, 2015, p. 2.

38 Knezys S., Lietuvos kariuomenès naikinimas (1940 m. birželio 15 d.-1941 m.), Genocidas ir rezistencija, 2004. 
26084 kariai ir 2031 civilis tarnautojas, iš jų - 1728 karininkai, 2091 liktinis karys (372 viršilos, 985 puskarininkiai, 393 jaunesnieji puskarininkiai, 341 puskarininkis kandidatas) ir 22265 kareiviai (1114 jaunesniųju puskarininkių, 2301 grandinis, 18850 eilinių) $)^{39}$. Kariuomenès rezervą sudarè 120400 atsargos karių.

Lietuvos kariuomenès gynybini pajègumą gerokai didino Lietuvos šaulių sąunga, pavaldi kariuomenès vadui. Šaulių sąjunga tuo laikotarpiu turejo per 62000 narių, iš jų 10000 - mokinių ${ }^{40}$. Šaulys buvo kas antras mokytojas, aukštųjų mokyklų dèstytojas, inžinierius. Iš apskričių šaulių būrių ir kuopų buvo sudarytos 22 rinktinès, dar atskirą rinktinę sudarè šauliai geležinkelininkai. Kiekviena rinktinè turejjo 40 būrių ir kuopų. Iš viso buvo apie 1200 šaulių būrių ${ }^{41}$. Šaulių rinktinių ir kuopų vadais buvo paskirti Lietuvos kariuomenès atsargos karininkai.

Kariuomenè buvo ginkluota 159501 šaunamuoju ginklu, 5960 kulkosvaidžių ir minosvaidžių, 603 artilerijos pabūklais, 46 šarvuočiais ir tankais, 118 lèktuvų.

Taigi, Lietuvos kariuomenè turèjo nemažas pajègas, pakankamai didelị ir gerai parengtą rezervą, tačiau tai nebuvo panaudota kraštui ginti. Vyriausybei nusprendus priimti Maskvos ultimatumą, prezidentas ir krašto apsaugos ministras pasiskubino palikti Lietuvą, palikę ir kariuomenę likimo valiai, nedavę jokių i̇sakymų, jokių nurodymų, nieko nepaaiškinę ${ }^{42}$.

Dauguma karininkų reiškè pasyvų protestą, kiti rengèsi sukilimui.

Birželio 15-ąją, vakare, ị Kauną su grupe aukštų pareigūnų atskrido Sovietų Sąungos užsienio reikalų liaudies komisaro pavaduotojas Vladimiras Dekanozovas, paskirtas SSRS vyriausybės ypatinguoju igaliotiniu Lietuvoje. İkūręs savo štabą buvusios SSRS pasiuntinybės Lietuvoje pastate, jis nedelsdamas émési veiklos ${ }^{43}$.

Pirmąją okupacijos dieną eiti krašto apsaugos ministro pareigas paskirtas kariuomenès vadas div. gen. Vincas Vitkauskas iš karto tapo

\footnotetext{
39 Ten pat.

40 Ten pat.

41 Ten pat.

42 Ten pat.

43 Knezys S., Lietuvos kariuomenès naikinimas (1940 m. birželio 15 d.-1941 m.), Genocidas ir rezistencija, 2004.
} 
Kremliaus emisaro Vladimiro Dekanozovo marionete.

Pirmomis okupacijos dienomis Kariuomenès štabe buvo gautas Sovietų Sąungos pasiuntinio Lietuvoje Nikolajaus Pozdniakovo raštas su sąrašu karininkų, kuriuos jis reikalavo nedelsiant atleisti iš kariuomenès kaip nepatikimus ${ }^{44}$.

1940 m. birželio 19 d. pirmieji iš kariuomenès buvo pašalinti karininkai, pasitraukę i užsienị kartu su Lietuvos prezidentu, - krašto apsaugos ministras brg. gen. Kazys Musteikis, plk. Juozas Musteikis, gen. št. plk. Aloyzas Valušis, gen. št. plk. ltn. Stepas Žukaitis.

1940 m. birželio $20 \mathrm{~d}$. prasidejo masinis karininkų šalinimas iš kariuomenès. Pirmiausia iš kariuomenès buvo atleidžiami, okupantų požiūriu, patys pavojingiausi karininkai.

V. Dekanozovo reikalavimu birželio pabaigoje-liepos mèn. buvo išleisti $\mathfrak{i}$ atsargą arba paskirti $\mathfrak{i}$ kitas pareigas beveik visi divizijų, pulkų, rinktinių, atskirųjų batalionų vadai, valdybų viršininkai, karo komendantai. Eiti ankstesnes pareigas buvo palikti tik Aukštosios karo mokyklos viršininkas div. gen. Stasys Raštikis, I pėstininkų divizijos vadas brg. gen. Jonas Černius, karo aviacijos viršininkas brg. gen. Antanas Gustaitis, Karo aviacijos mokyklos viršininkas plk. ltn. Viktoras Reimontas, 2-ojo ulonu pulko vadas plk. Kazys Gudelis, priešlèktuvinès apsaugos rinktinès vadas gen. št. plk. Antanas Sidabras ${ }^{45}$.

Panašiai buvo elgiamasi ir su žemesnio rango vadais - karininkai buvo perkeliami iš vienų dalių $\mathfrak{j}$ kitas arba keičiamos jų pareigos, paliekant toje pačioje dalyje. Per trumpą laiką ị naujas pareigas buvo paskirtas kas ketvirtas karininkas ${ }^{46}$.

Nuo 1940 m. birželio 19 d. iki 1940 m. rugpjūčio 27 d., iki Lietuvos liaudies kariuomené buvo ịtraukta ị Raudonosios armijos sudètị, iš Lietuvos kariuomenès buvo pašalinta 218 karininkų (90 proc. generolų, daugiau nei ketvirtadalis pulkininkų) ${ }^{47}$, iš jų: 2 divizijos generolai Edvardas Adamkavičius ir Mikas Rèklaitis; 8 brigados generolai - Viktoras Giedrys, Vladas Mieželis, Kazys Musteikis, Vladas Nagevičius, Kazys Navakas, Klemensas Popeliučka, Kazys Tallat-Kelpša ir Emilis Vimeris;

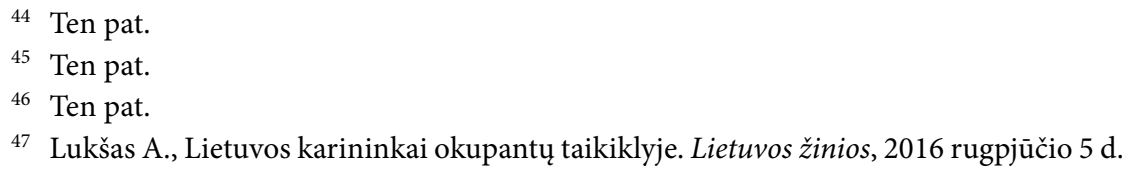


29 pulkininkai - Jonas Acus-Acukas, Jonas Andrašiūnas, Vladas Braziulis, Andrius Butkūnas ir kiti; 33 pulkininkai leitenantai; 32 majorai; 114 jaunesniųjų karininkų ${ }^{48}$.

Iki 1941 m. sausio mèn. iš kariuomenès papildomai buvo atleisti 292 karininkai, iš jų: 2 divizijos generolai - Stasys Pundzevičius ir Stasys Raštikis; 3 brigados generolai - Juozas Barzda-Bradauskas, Kazys Sprangauskas ir Stasys Zaskevičius; 16 pulkininkų - Jonas Augevičius, Domas Grabys, Juozas Grigiškis, Vladas Ingelevičius, Juozas Šarauskas ir kiti; 44 pulkininkai leitenantai; 50 majorų; 177 jaunesnieji karininkai ${ }^{49}$.

$1940 \mathrm{~m}$. liepos 3 d. buvo paskelbtas Lietuvos kariuomenès pertvarkymo įstatymas - Lietuvos kariuomene buvo pavadinta Lietuvos liaudies kariuomene, įsteigta politinių vadų institucija ir kariuomenès propagandos skyrius.

1940 m. liepos 11 d. sustabdyta Šaulių sajungos veikla.

1940 m. rugpjūčio 27 d. Lietuvos liaudies kariuomené, egzistavusi 56 dienas, buvo panaikinta. Nuo tos dienos ji tapo Raudonosios armijos 29-uoju teritoriniu šaulių korpusu, ị kurio sudètị ịejo 179-oji ir 184-oji šaulių divizijos. Korpuso vadu buvo paskirtas div. gen. V. Vitkauskas, korpuso vado pavaduotoju - brg. gen. F. Žemaitis, korpuso štabo viršininku - brg. gen. J. Černius ${ }^{50}$. Liaudies kariuomenès I pėstininkų divizija pavadinta 179-aja šaulių divizija, jos vado pareigas eiti paskirtas div. gen. S. Pundzevičius, II péstininkų divizija pavadinta 184-ąja šaulių divizija, jos vado pareigas eiti paskirtas brg. gen. Vladas Karvelis ${ }^{51}$.

Nuo 1940 m. vasaros pabaigos NKVD darbuotojai, komisarai ir vadinamieji politrukai (politiniai vadovai) sudarinejo nepatikimų lietuvių karių sąrašus. Iš maždaug 12000 lietuviškojo 29-ojo teritorinio šaulių korpuso karių ị juos pateko 3200 karininkų, jaunesniųjų vadų ir kareivių, kuriuos buvo numatyta suimti pirmiausia ${ }^{52}$.

Iš kariuomenès atleisti karininkai susidūrè su finansiniais sunkumais,

\footnotetext{
48 Knezys S., Lietuvos kariuomenès naikinimas (1940 m. birželio 15 d.-1941 m.), Genocidas ir rezistencija, 2004.

49 Ten pat.

50 Knezys S., Lietuvos kariuomenès naikinimas (1940 m. birželio 15 d.-1941 m.), Genocidas ir rezistencija, 2004.

51 Ten pat.

52 Anušauskas A., Teroras. 1940-1958 m., Vilnius, 2012, p. 47.
} 
neturèjo galimybių greitai susirasti kito tinkamo darbo ir išlaikyti šeimų. Daugumos šeimos buvo išlaikomos tik iš karininkų algos, jų žmonos paprastai rūpinosi šeimos buitimi, vaikų priežiūra ir ugdymu.

1940 m. rugpjūčio 27 d. panaikinus Krašto apsaugos ministeriją, buvo sustabdytas pensijų mokejjimas ị atsargą išleistiems karininkams. Jų materialinè padètis tapo dar sunkesnè.

Daugelis iš kariuomenès atleistų karininkų beveik iš karto buvo suimti ir atsidūrẻ kalejjimuose, konfiskuotas jų nekilnojamasis turtas.

Skaudžiai nukentejo ir represuotų karininkų šeimos. Suimtų karininkų šeimos buvo paliktos be pragyvenimo šaltinio, konfiskuotas jų turtas, o jos pačios ištremtos i tolimus ir atšiaurius Sovietų Sajungos rajonus. Ten nuo bado, šalčio ir ligų mirè mažamečiai vaikai, vyresnio amžiaus tèvai. Grịžus iš tremties buvo visaip kliudoma prisiregistruoti, įsidarbinti, vaikams - studijuoti norimą specialybę aukštosiose mokyklose.

\section{LIETUVOS KARININKŲ SUĖMIMAI IR TARDYMAI}

\subsection{Lietuvos karininkų suèmimai}

Lietuvos kariuomenès karininkų suėmimai prasidejjo 1940 m. liepos mèn. Pirmas buvo suimtas $\mathfrak{i}$ atsargą išleistas Ginklavimo valdybos Bendrojo skyriaus viršininkas plk. Mykolas Kalmantas, anksčiau vadovavęs Šaulių sąungai. Kiek vèliau buvo suimti ị atsargą išleisti karo prokuroras brg. gen. Emilis Vimeris, Šaulių sąjungos vadas plk. Pranas Saladžius ir kt. ${ }^{53}$

Liepos mèn. Lietuvos kariuomenę sukrètè masiniai karių suėmimai „maištingame“ 9-ajame Lietuvos kunigaikščio Vytenio pėstininkų pulke, kuris 1940 m. birželio 15 d. krašto apsaugos ministro brg. gen K. Musteikio nurodymu turejjo užtikrinti prezidento A. Smetonos pasitraukimą $\mathfrak{i}$ Vokietiją. Nors šis sumanymas taip ir liko neigyvendintas, tačiau to pakako, kad pulkas atsidurtų nepatikimųjų sąraše - pulko vadas gen. št. plk. Antanas Gaušas buvo atleistas iš kariuomenès, o pats pulkas

\footnotetext{
53 Knezys S., Lietuvos kariuomenès naikinimas (1940 m. birželio 15 d.-1941 m.), Genocidas ir rezistencija, 2004.
} 
liepos 5 d. perkeltas ị Pabradès poligoną ir vèliau išformuotas. $1940 \mathrm{~m}$. liepos mènesị buvo suimti 8 šio pulko karininkai - mjr. Jonas Brizgys, kapitonai Viktoras Klimavičius, Antanas Malakauskas, leitenantai Juozas Kiveris, Jonas Vladas Sagenas, Vacys Skinderis, jaunesnieji leitenantai Jonas Naikelis ir Petras Vismantas. Penki karininkai, tarp jų ir pulko štabo viršininkas gen. št. plk. ltn. Motiejus Naujokas, buvo išleisti i atsargą ${ }^{54}$.

Liepos men. pabaigoje buvo suimta visa Kariuomenès štabo II (žvalgybos) skyriaus vadovybė - gen. št. plk. Kostas Dulksnys, plk. ltn. Juozas Matusaitis ir plk. ltn. Petras Kirlys. Vèliau suimta ir 14 šio skyriaus karininkų. Enkavėdistus ${ }^{55}$ ypač domino Lietuvos žvalgybos agentūra ir ryšiai su Prancūzijos, Vokietijos ir kitų šalių žvalgybomis. Gen. št. plk. K. Dulksnys, plk. ltn. P. Kirlys ir plk. ltn. J. Matusaitis kartu su buvusiu vidaus reikalų ministru ats. brg. gen. Kaziu Skuču, Valstybès saugumo departamento direktoriumi Augustinu Povilaičiu ir kitais suimtaisiais liepos $23 \mathrm{~d}$. buvo išvežti ị Maskvą, ten tardyti, kankinti ir, prasidejjus Vokietijos-Sovietų Sajungos karui, sušaudyti Butyrkų kalejji$\mathrm{me}^{56}$. Kiti 8 šio skyriaus karininkai buvo išvežti ị kitus Sovietų Sąjungos kalejjimus ir lagerius, o 6, kalinti Lietuvoje, prasidejus karui, iš kalejjimų buvo išlaisvinti, bet jau tardymu palaužta sveikata. Tik vienas šio skyriaus raštvedys „dèl etatų mažinimo" išèjęs ị atsargą išvengè arešto.

Iki 1940 m. rugpjūčio pabaigos buvo suimtas 271 karininkas, 33 puskarininkiai, 15 eilinių ir 4 civiliai tarnautojai (ị suimtų karininkų skaičiu itrauktas ir atsargos karininkų skaičius $)^{57}$.

1941 m. birželio 10 d. vadovybès sprendimu ị Maskvos F. Dzeržinskio artilerijos akademijos tobulinimosi kursus buvo išsiųsti 14 aukšto rango 29-ojo teritorinio šaulių korpuso karininkų: korpuso artilerijos viršininkas gen. mjr. ${ }^{58}$ Vincas Žilys, artilerijos štabo viršininkas plk. Kazys Abaras, 179-osios divizijos artilerijos viršininkas gen. mjr. Jonas Juodišius,

\footnotetext{
54 Ten pat.

55 Enkavėdistas - NKVD darbuotojas, tardytojas.

56 Knezys S., Lietuvos kariuomenès naikinimas (1940 m. birželio 15 d.-1941 m.), Genocidas ir rezistencija, 2004.

57 Ten pat.

58 Gen. mjr. - generolas majoras - sovietinès kariuomenès karinis laipsnis, atitinkantis Lietuvos kariuomenès brigados generolo laipsni.
} 
štabo viršininkas pplk. ${ }^{59}$ Antanas Malijonis, 618-ojo pulko vadas mjr. Antanas Dapkus, 619-ojo artilerijos pulko vadas pplk. Adomas Jonavičius, 184-osios divizijos artilerijos viršininkas plk. Leonas Rupšys, štabo viršininkas plk. Vincas Jasulaitis, 617-ojo artilerijos pulko vadas plk. Alfonsas Šklèrius, 615-ojo artilerijos pulko vadas plk. Vladas Sidzikauskas, papulkininkiai Petras Daukšys, Edvardas Tallat-Kelpša, Pranas Matulis ir mjr. Balys Steikūnas. ${ }^{60}$ I kursus, kurie vyko akademijos Gorochovetsko poligone, buvo atsiųsta ir 13 Latvijos bei 15 Estijos karininkų artileristų.

Naktị iš birželio 28-osios ị 29-ąją visi 42 Baltijos šalių karininkai buvo iškviesti i poligone buvusị akademijos štabą ir suimti apkaltinus antisovietine veikla ir prastu pavaldinių auklejimu ${ }^{61}$. Griežtai saugomi suimti karininkai buvo nuvežti ị Gorkio kalejimą, o iš ten per Krasnojarską ir Dudinkos uostą - i Norilsko lagerius.

1941 m. gegužès 20-22 d. lietuviškos 29-ojo šaulių teritorinio korpuso dalys buvo perkeltos ị vasaros stovyklas: korpuso štabas ir korpuso štabo pavaldumo dalys, 179-oji šaulių divizija - ị Pabradès, 184-oji - i Varénos poligoną. Su ginklais, bet be šaudmenų. Ginklus buvo ịsakyta griežtai saugoti įrengtose šaudyklose. Kariams buvo griežtai uždrausta išeiti už stovyklų ribų. Aplink lietuviškąsias dalis buvo išdèstytos sovietų dalys. Lietuviai atsidūré apsuptyje $\mathrm{e}^{62}$. Birželio $10-12 \mathrm{~d}$. beveik visi vadai lietuviai buvo pakeisti rusais.

1941 m. birželio 14-ąją Pabradès ir Varènos poligonuose buvo nuginkluoti ir suimti 236 29-ojo šaulių teritorinio korpuso karininkai ir apie 40 puskarininkių. Jie iš pradžių nuvežti ị Juchnovo karo belaisvių stovyklą (netoli Maskvos), vèliau pervežti ị Norillagą Krasnojarsko krašte ir ten kalinti. Per masinius suėmimus tik nedaugelis karininkų jų išvengè, nes tuo metu dèl ịvairių priežasčių buvo išvykę iš dalinių ${ }^{63}$.

\footnotetext{
59 Pplk. - papulkininkis - sovietinès kariuomenès karinis laipsnis, atitinkantis Lietuvos kariuomenès pulkininko leitenanto laipsnị.

60 Knezys S., Lietuvos kariuomenès naikinimas (1940 m. birželio 15 d.-1941 m.), Genocidas ir rezistencija, 2004.

61 Ten pat.

62 Ten pat.

63 Knezys S., Lietuvos kariuomenès naikinimas (1940 m. birželio 15 d.-1941 m.), Genocidas ir rezistencija, 2004.
} 
Iš viso Norillage buvo kalinama 270 Lietuvos karininkų: 3 generolai (div. gen. Zenonas Gerulaitis, brg. gen. Jonas Juodišius ir brg. gen. Vincas Žilys), 13 pulkininkų, 19 pulkininkų leitenantų, 22 majorai ir 111 jaunesniųjų karininkų ${ }^{64}$.

Šiam masiniam suemimui korpuso NKGB Ypatingasis skyrius ${ }^{65}$ buvo pasirengęs jau birželio pradžioje ${ }^{66}$. Buvo planuojama ir antroji lietuvių karių, tarnaujančių 29-ajame šaulių teritoriniame korpuse, suėmimo banga, bet sutrukdè $1941 \mathrm{~m}$. birželio 22-ąją prasidejjęs Vokietijos-Sovietų Sąungos karas.

\subsection{Tardymai}

Tardydami suimtuosius enkavėdistai naudojo per masines represijas Sovietų Sąungoje „ištobulintą“ tardymo patirtị. Jų išmonei ir žiaurumui nebuvo ribų. Siekiant išgauti reikiamus parodymus, buvo naudojama apgaulè, psichologinis ir fizinis smurtas, kurio tikslas - pažeminti, išsekinti, ibauginti ir palaužti tardomajji.

Daugelis karininkų tardymų metu patyrẻ ịvairių sužalojimų. Tardomieji buvo spardomi kojomis, daužomi kumščiais, guminèmis lazdomis, kabelių nuopjovomis, badomi aštriais įrankiais, žalojami laužant pirštus, kankinami elektra, deginami lygintuvais ir cigaretèmis, verčiami stovèti ar sèdèti nejudant nepatogia poza valandų valandas, kabinami ant kablių už antrankiais surakintų rankų. Jiems buvo neleidžiama miegoti kelias paras iki visiško sąmonès aptemimo, neteikiama reikiama medicininè pagalba, jie buvo laikomi be viršutinių rūbų šaltuose kalejimų karceriuose, visiškoje tamsoje ar akinančioje šviesoje, marinami badu, kalinami perpildytose kamerose kartu su kriminaliniais nusikaltèliais ir pan.

Tardytojai suimtuosius stengèsi paveikti ir psichologiškai - grasino susidoroti su jų artimaisiais, apgauti - neva priešintis nebeverta, nes esą jau viskas žinoma, o prisipažinus ir davus reikiamus parodymus suimtasis būsiąs paleistas ị laisvę ar bus pagerintos jo kalinimo sąlygos. Plk. Jonas Petruitis Kauno sunkiųjų darbų kalejjimo rūsio kameroje buvo spe-

\footnotetext{
64 Ten pat.

65 Sovietų Sąjungos karinès kontržvalgybos padaliniai.

66 Knezys S., Lietuvos kariuomenès naikinimas (1940 m. birželio 15 d.-1941 m.), Genocidas ir rezistencija, 2004.
} 
cialiai laikomas su psichiškai nesveiku kaliniu, kuris ištisai rèkè, valgè savo išmatas ${ }^{67}$.

Enkavèdistai suimtiesiems sakè: „Žinokit, kad visi nusikaltimai, padaryti prieš Sovietų Sąungą bet kieno, bet kada ir bet kur, nepamirštami ir visi nusikaltèliai, pirmai galimybei atsiradus, yra baudžiami. Mūsų baudžiamasis kodeksas tą numato, todèl ir jūs būsite baudžiami pagal kodekso 58 straipsni.. "68

\subsection{Sovietinių represinių institucijų šnipai ir kolaborantai}

Informacijai iš tardomųjų išgauti, jiems ịtikinti duoti tardytojams reikiamus parodymus enkavèdistai kalejimų kamerose naudojo savo agentus ir informatorius, specialiai šiuo tikslu laikomus kalejjimuose ar užverbuotus iš pačių kalinių ir prižiūrètojų tarpo.

Okupantams talkino įvairaus plauko kolaborantai, skundikai ir šnipai - šimtai sovietų represinių tarnybų agentų ir informatorių, tarnavusių okupantams dèl politinių îsitikinimų, naudos, iš keršto ar baimès. Jie teikè informaciją apie karininkų ir karių politines nuotaikas, išleistų $\mathfrak{i}$ atsargą karininkų ir jų šeimų buvimo vietą, pasipriešinimo organizacijų veiklą ir narius, padejo sudaryti represuotinų asmenų ir jų šeimų sąrašus.

Agentūra taip pat plačiai naudota kalejjimuose, lageriuose ir tremties vietose suimtųjų, kalinių ir tremtinių nuotaikoms stebèti, reikiamai informacijai iš jų išgauti, paskatinti duoti reikiamus parodymus tardymų metu. Kalejimų ir lagerių NKVD operatyviniai padaliniai buvo ịpareigoti verbuoti agentus ir informatorius iš kalinių, prižiūrètojų ir lagerių administracijos darbuotojų tarpo kaliniams stebėti, kontrrevoliucinèms organizacijoms išaiškinti ${ }^{69}$.

\footnotetext{
67 Petruitis J., Kaip jie mus sušaude, Kaunas, 1943.

68 Ten pat.

691939 m. spalio 8 d. NKVD nurodymas Nr. 46 „Dèl karo belaisvių operatyviniočekistinio aptarnavimo NKVD lageriuose“.
} 


\section{KALINIŲ EVAKUACIJA IR ŽUDYMAS PRASIDÉJUS KARUI}

1941 m. birželio 22 d. prasidejjus Vokietijos-Sovietų Sąjungos karui, NKVD ir $\mathrm{NKGB}^{70}$ teko skubiai spręsti Lietuvos kalèjimuose laikomų kalinių likimą. Neturint laiko ir galimybių jų evakuoti, kai kurie kaliniai buvo žudomi vietoje (NKVD terminologija - evakuoti pagal I kategoriją), kiti išvežti ị kitus Sovietų Sąjungos kalejjimus (evakuoti pagal II kategoriją).

Dauguma iš Lietuvos ị Sovietų Sąjungos kalejimus ir lagerius išvežtų suimtųų dar nebuvo nuteistieji, o tik tardomieji (rus. k. следственно арестованные).

Pirmosiomis karo dienomis Rainiuose okupantų buvo žvėriškai nužudyti Telšių kalèjime kalinti ats. j. ltn. Jonas Antanavičius, ats. j. ltn. Pranas Daukša, ats. j. ltn. Antanas Dibisteris, ats. j. ltn. Jonas Jakštas, ats. j. ltn. Vladas Petronaitis ir ats. j. ltn. Česlovas Šalkauskas, Panevėžyje - plk. Juozas Žemgulys, ats. j. ltn. Stasys Mačiulis, Zarasuose plk. ltn. Ignas Pašilys-Podgaiskis. Be žinios dingo suimti plk. ltn. Antanas Karosas, ltn. Vytautas Stankūnas ir j. ltn. Kajetonas Matas Kaunas.

I Gorkio kalejjimą (dabar Žemutinio Naugardo sritis) buvo išvežtas buvęs žemès ūkio ministras ats. ltn. Statys Putvys, plk. Domas Grabys, gen. št. mjr. Vytautas Bulvičius, ị Sol Ilecko kalejjimą (dabar Permès sritis) - ats. gen. ltn. Kazimieras Ladiga ir kiti kaliniai.

Didžiausia, apie 120 kalinių, grupe autobusais su ginkluota palyda buvo išvežta iš Kauno kalèjimo ị Minską ir Polocką.

Minsko kalèjime nuo grupès buvo atskirti ir sušaudyti 17 kalinių, jau nuteistų mirties bausme, tarp juc - vidaus reikalų ministras ats. plk. Steponas Rusteika, mjr. Stasys Šaulys, aviacijos kpt. Albertas Gustavas Švarplaitis, gen. št. plk. ltn. K. Pranskonio žmona Vanda Pranskonienè ir kiti.

Likusi iš Kauno kalejjimo atvežta kalinių grupe kartu su kitais 2000 kalinių pėsčiomis kolona išvaryta ị Rusijos gilumą Mogiliavo kryptimi. Koloną pasivijus vokiečių priešakiniams daliniams, enkavèdistai ties Červene nusprende kalinius sušaudyti. Čia žuvo krašto apsaugos ministras ats. plk. Balys Giedraitis, plk. Juozas Šarauskas, mjr. Jonas Špoke-

70 NKGB (rus. k. Народный комиссариат государственной безопасности - Valstybès saugumo liaudies komisariatas) - Sovietų Sąjungos valstybès saugumo institucija. 
vičius, ats. mjr. Vincas Daudzvardas, mjr. Vladas Opulskis, kpt. Stasys Gromnickas, vyr. ltn. Jonas Tatarincevas, ltn. Juozas Jakaitis. Žudynių metu pavyko išsigelbèti apie 40 kalinių, atvežtų iš Kauno kalejimo, tarp jų - ats. plk. Jonui Petruičiui, plk. Antanui Šovai, plk. Juozui Tumui, plk. Giliarui Urbonui, aviacijos kpt. Stasiui Jasiunskui, kpt. Osvaldui Žadvydui ir ltn. Alfonsui Žebrauskui.

Kita kalinių grupe, išvežta iš Kauno kalèjimo, buvo sušaudyta prie Bigosovo geležinkelio stoties (Pskovo srityje), tarp jų - Nepriklausomybès Akto signataras, ministro pirmininko pavaduotojas Kazimieras Bizauskas ir kpt. Antanas Gedmantas.

Gelbėdami savo kailị enkavėdistai nespejo nužudyti ar išvežti visų kalinių. Lietuvos kalejjimuose likusiems kaliniams pavyko išsilaisvinti prasidejjus Birželio sukilimui. Iš kalèjimų buvo išlaisvinti div. gen. Mikas Reklaitis, ats. gen. ltn. Teodoras Daukantas, ats. gen. ltn. Jonas GalvydisBykauskas, ats. gen. ltn. Petras Kubiliūnas, ats. gen. ltn. Petras Šniukšta, brg. gen. Emilis Vimeris, plk. Mykolas Kalmantas, plk. Pranas Saladžius, gen. št. plk. ltn. Kazys Pranskonis, plk. ltn. Alfonsas Baniulis, kpt. Viktoras Klimavičius ir kiti.

\section{LIETUVOS KARININKŲ ŽŪTYS 29-AJAM ŠAULIŲ TERITORINIAM KORPUSUI TRAUKIANTIS IŠ LIETUVOS}

Prasidejus Vokietijos-Sovietų Sąjungos karui, sovietų daliniai apsupo 29-ojo šaulių teritorinio korpuso 179-osios ir 184-osios šaulių divizijų, dislokuotų Pabradès ir Varènos poligonuose, stovyklas, užblokavo visus kelius. Buvo paskelbtas ịsakymas nè vienam kariui neišeiti iš stovyklos be specialaus leidimo - sulaikyti be leidimo už stovyklos ribų kariai būsią perduoti karo tribunolui ir sušaudyti. Birželio $22 \mathrm{~d}$. vakare divizijoms buvo paskelbta, kad kitą dieną jos išvyks ị Rusijos gilumą ir prie Maskvos užims gynybines pozicijas ${ }^{71}$.

Tačiau lietuviai kariai nenorejo trauktis ị Rusiją. Dauguma jų buvo

71 Knezys S., Lietuvos kariuomenès naikinimas (1940 m. birželio 15 d.-1941 m.), Genocidas ir rezistencija, 2004. 
tvirtai apsisprendę bet kokia kaina likti Lietuvoje, priešintis priverstiniam pasitraukimui ị Rusijos gilumą.

Varènos poligone dislokuotos 184-osios šaulių divizijos kariai sukilo, pasinaudoję rusų daliniuose kilusiu sąmyšiu. Divizijai pavyko beveik be aukų atsiskirti nuo teritorinio korpuso ir birželio $28 \mathrm{~d}$. grịžti ị Vilnių, $\mathfrak{i}$ savo nuolatinę dislokacijos vietą.

Gerokai sunkiau buvo 179-osios šaulių divizijos kariams lietuviams. Divizijai buvo įsakyta iš Pabradès-Švenčionèlių rajono žygiuoti link Adutiškio, paskui trauktis tolyn ị Rusiją. $1941 \mathrm{~m}$. birželio 27 d. 179-oji šaulių divizija perejo Lietuvos sieną ir traukèsi tolyn ị rytus. Divizijoje tarnavę kariai lietuviai ginklu pasipriešino prievartiniam varymui i $\mathrm{Ru}-$ siją. Vienas didesnių susiremimų su sovietais ịvyko prie Noricos kaimo, kur žuvo 18 lietuvių karių. Miške prie Žukovo kaimo palaidotas vienas karininkas ir dešimt karių. Kitas smarkus lietuvių susirėmimas su sovietais įvyko prie Glubokojès kaimo. Čia grupei lietuvių pavyko ištrūkti iš raudonarmiečių priežiūros ir išsisklaidžius grị̌žti ị Lietuvą ${ }^{72}$.

I Rusiją pasitraukè tik labai nedidelè 29-ojo šaulių teritorinio korpuso dalis. Šio korpuso, kaip Raudonosios armijos junginio, nebeliko ir jo likučiai buvo išformuoti ${ }^{73}$.

Už pasipriešinimą priverstiniam pasitraukimui ị Rusiją buvo be teismo sušaudyta 11 lietuvių karininkų: mjr. Vladas Vaitkus, mjr. Stasys Šaulys, kpt. Vincas Sikorskis, kpt. Adolfas Pilvelis, kpt. Juozas Puknys, kpt. Povilas Kaladè, ltn. Julius Jankauskas, ltn. Petras Gavulis, j. ltn. Vaclovas Lèvūnas, j. ltn. Juozas Kęstutis Kazėnas, j. ltn. Juozas Kamičaitis. J. ltn. Aleksandrą Sviklį raudonarmiečiai subadè durtuvais ${ }^{74}$.

3 karininkai, nenorèdami trauktis ị Rusiją nusišovè patys: plk. ltn. Otto Milaševičius, mjr. Aleksas Bartkus, ltn. Jonas Navikevičius. Plk. ltn. Otto Milaševičius nusišovė Adutiškyje, kareiviams taręs: „Brangūs Lietuvos kariai, čia paskutinis Lietuvos miestelis. Toliau nèra mums kur trauktis. "

Plk. Antanas Sidabras ir plk. ltn. Juozas Lavinskas buvo suimti ir véliau sušaudyti Norilsko lageriuose, juose taip pat buvo sušaudyti kpt. Stasys Gromickas, ltn. Kęstutis Kvedaras, j. ltn. Vladas Pūkis-Pūkelevičius.

\footnotetext{
72 Ten pat.

73 Ten pat.

74 Ten pat.

75 Ten pat.
} 
Norilsko lageriuose buvo ¡kalinti mjr. Povilas Krištopavičius, kapitonai Stasys Balčiūnas, Kazys Povilaitis, ltn. Marijonas Stankevičius ir kiti karininkai. Kelionès ị lagerị metu mirè j. ltn. Viršila ${ }^{76}$.

\section{KARININKŲ KALINIMAS, JŲ ŽŪTYS KALĖJIMUOSE IR LAGERIUOSE}

Prasidejęs Vokietijos-SSRS karas sutrukdè okupantams igyvendinti visus savo planus - ne visi represuoti numatyti asmenys buvo surasti, suimti, ịkalinti ar ištremti.

Dalis iš kariuomenès atleistų karininkų, siekdami išvengti suėmimo, nenakvojo namuose, išvyko pas gimines ị kitus miestus ar kaimus, persikèle i savo sodybas arba pradejjo slapstytis.

Šią situaciją gerai iliustruoja gen. Vinco Grigaliūno-Glovackio atvejis. Prasidejus karininkų suėmimams, generolas iš Kauno išvažiavo ị Vilnių pas žmonos seserị, o bičiulių ir artimųjų ịspètas apie jo paiešką persikèlè ị kaimą Gardino srityje, kur apsimetęs beraščiu iki prasidedant karui ganė kaimo gyvulių bandą. „Kažkas yra pasakęs, kad nuo plèšikų geriausia yra pasislèpti arti jų lindynès. Patraukiau ne ị Vokietiją, o poliariškai priešinga kryptimi, t. y. Baltgudijos link - i Gardino sriti, kur jaunystèje teko mokytis. Taip pat mokejjau kalbèti baltgudiškai. Čia galbūt ir pavyks prastai apsitaisius kuriame nors kaimelyje issitaisyti skerdžiumi ${ }^{\text {“77, }}$, savo atsiminimuose rašè generolas.

\subsection{Išleistų i atsargą karininkų suẻmimas birželio 14-15 d.}

Išleistų ị atsargą karininkų masinị suėmimą rengė LSSR NKGB. Iš šio komisariato vadovo P. Gladkovo $1941 \mathrm{~m}$. birželio $11 \mathrm{~d}$. rengtos pažymos matyti, kad buvo ketinama suimti $74 \mathfrak{i}$ atsargą išleistus karininkus. To paties P. Gladkovo $1941 \mathrm{~m}$. birželio 19 d. pasirašytoje suvestinèje nuro-

\footnotetext{
76 Knezys S., Lietuvos kariuomenès naikinimas (1940 m. birželio 15 d.-1941 m.), Genocidas ir rezistencija, 2004.

77 Grigaliūnas-Glovackis V., Generolo atsiminimai. II-III dalys, ats. red. Gintautas Surgailis, Vilnius, 2017, p. 286-287.
} 
dyta, kad suimti 104 ir ištremtas 221 - iš viso 325 karininkai. I ṣ̌̆ skaičių itraukti ir buvę Lenkijos kariuomenès karininkai ${ }^{78}$.

$1941 \mathrm{~m}$. birželio $14 \mathrm{~d}$. kartu su šimtais valstybès tarnautojų, politinių partijų ir visuomeninių organizacijų narių, teisininkų, policijos pareigūnų, geležinkelių tarnautojų, verslininkų, mokytojų, žurnalistų ir ūkininkų buvo suimtos ir kelios dešimtys Lietuvos kariuomenès atsargos karininkų.

Suimtieji geležinkelio stotyse buvo atskirti nuo šeimų ir įsodinti ị atskirus ešelonus. Suimtieji buvo išvežti $\mathfrak{i}$ lagerius, o jų šeimos $\mathfrak{i}$ tremti $-\mathfrak{i}$ Komijos ASSR, Altajaus ir Krasnojarsko kraštus, Tomsko sritị. 1942 m. dauguma šeimų iš Altajaus krašto perkeltos ị Jakutijos šiaurę, prie Laptevų jūros ${ }^{79}$. Čia daugelis jų žuvo nuo šalčio ir bado.

Ešelonus saugojo ginkluoti NKVD konvojaus kariuomenès dalinių kariai. Suimtieji ir tremtiniai buvo vežami kroviniams ir gyvuliams vežti skirtuose vagonuose su spygliuota viela apraizgytais ir lentomis užkaltais langais. Vagonuose buvo sukalti ištisiniai dviaukščiai gultai. Tualetą atstojo grindyse iškirsta skyle ir sukaltas lovys, pritvirtintas prie vagono sienos. I kiekvieną vagoną buvo sugrūsta po keliasdešimt žmonių.

Iš namų pasiimto maisto atsargos greitai baigèsi, ir suimtieji buvo priversti tenkintis konvojaus duodama sūria žuvimi, nuo kurios labai troškino. Vagonuose nuo saulès ikkaitinto metalinio stogo buvo labai karšta, dèl žmonių pertekliaus ir užkaltų langų labai trūko oro. Konvojus duodavo po kibirą vandens vagonui tik geležinkelio stotyse, tad suimtuosius kankino troškulys, ne visiems tekdavo vandens.

Ešelonai su suimtaisiais ir tremtiniais judèjo lètai, ilgai stovejo geležinkelio stotyse, praleisdami i frontą vykstančius ešelonus su karine technika ir kariais. Suimtieji i paskirties punktus buvo vežami kelias savaites. Ne visi ištvèré tokias sąlygas - daugelis nusilpo, sirgo, nemažai mirè. Mirusiuosius sustojus ešelonui tiesiog iškeldavo iš vagonų. Jų laidoti nebuvo laiko.

Masinio trėmimo metu $1941 \mathrm{~m}$. birželio $14 \mathrm{~d}$. buvo suimta ir išvežta ị lagerius 3915 asmenų, daugiausia nuo tremiamų šeimų atskirtų vyrų. Dauguma - 2425 asmenys - buvo ịkalinti Rešotų ir Norilsko lageriuose

\footnotetext{
78 Anušauskas A., Teroras. 1940-1958 m., Vilnius, 2012, p. 63.

79 Burauskaitė T. B., 12-asis kilometras: 1942-1943 m. Sverdlovske sušaudyti Lietuvos piliečiai, Vilnius, 2015, p. 6.
} 
Krasnojarsko krašte, 387 - Sevurallage, Sverdlovsko srityje, likusieji Kazachijos SSR, Molotovo ir Vologdos sričių lageriuose ${ }^{80}$.

\subsection{Kalinimo sąlygos}

Lietuvos karininkai buvo kalinami nežmoniškomis sąlygomis tolimuose, atšiauriuose Sovietų Sajungos rajonuose įkurtuose lageriuose. Jie buvo pusbadžiu laikomi antisanitarinèmis sąlygomis, be tinkamos šiaurès klimatui aprangos ir apavo, verčiami po 12 valandų per parą dirbti sunkiausius miško kirtimo, kalnakasybos, kelių tiesimo darbus, taip pat šachtose ir metalurgijos gamyklose.

Kaliniai barakuose miegojo tiesiog ant plikų gultų, apsikloję savo drabužiais. Nesant elektros, patalpos buvo apšviečiamos balanomis. Juos maitino du kartus per dieną - skysta, permatoma, dažnai be druskos sriuba, trupučiu košès ir 400 gramų šlapios duonos, vakare - tik tokia pat sriuba. Nebegalintiems dirbti tekdavo vos po 300 gramų duonos ${ }^{81}$. Dèl maisto trūkumo prasidejjo badas, kaliniai visiškai išseko, daugelis susirgo avitaminoze. Lagerių medicinos punktuose nebuvo nei reikiamų vaistų, nei medicininių instrumentų. Atleisti sergantị kalinị nuo darbo lagerio gydytojai galèjo tik jam turint daugiau nei $+39^{\circ} \mathrm{C}$ temperatūros ${ }^{82}$.

1941-1942 m. žiemą lageriuose miré apie trečdalis kalinių, dauguma - nuo nepakeliamai sunkaus darbo, bado, šalčio, išsekimo ir ligų, negavę reikiamos medicininès pagalbos. Mirusieji buvo tiesiog užkasami bendrose duobèse kartu su kitais likimo broliais, nesilaikant visuotinai priimtų laidojimo apeigų.

Ne ką geresnès kalinimo sąlygos buvo ir kalejimuose. Kaliniai buvo marinami badu, laikomi perpildytose kamerose kartu su kriminaliniais nusikaltèliais.

${ }^{80}$ Burauskaitė T. B., 12-asis kilometras: 1942-1943 m. Sverdlovske sušaudyti Lietuvos piliečiai, Vilnius, 2015, p. 2.

81 Ten pat, p. 8.

82 Tekorius A., Sušaudytoji vyriausybè, Lietuvos žinios, 2012 rugsèjo 19 d., p. 10-11. 


\subsection{Tardymai lageriuose}

Pirmieji kalinių tardymai lageriuose prasidejjo 1941 m. rudeni. Tardytojus labiausiai domino kalinių kilmé, eitos pareigos, priklausymas „kontrrevoliucinèms nacionalistinèms buržuazinèms" partijoms ir visuomeninèms organizacijoms, „karinei-fašistinei“ Šaulių sąjungai, gauti valstybès apdovanojimai ${ }^{83}$.

Tardomieji buvo verčiami prisipažinti dèl nepadarytų nusikaltimų, duoti reikiamus parodymus, pasirašyti tardytojų sukurptus apklausos protokolus.

Tardymas buvo atliekamas supaprastinta tvarka. Po kelių apklausų pagal Rusijos SFSR baudžiamojo kodekso 58 straipsnio 13 dalį buvo pateikiami kaltinimai - aktyvi kova su revoliuciniu judejjimu ar priklausymas kontrrevoliucinei partijai. Tai neteisèti ir absurdiški kaltinimai suverenios valstybès piliečiams, valstybès tarnautojams, kariams, vykdžiusiems savo konstitucinę pareigą - ginti šalį nuo priešų, užtikrinti jos nepriklausomybę ir konstitucinę santvarką. Kaltinamosios išvados, patvirtintos teritorinių NKVD valdybų vadovų ir prokurorų, buvo perduotos SSSR NKVD Ypatingajam pasitarimui ${ }^{84}$, kuris, nedalyvaujant kaltinamiesiems, liudytojams ir gynejjams, formaliai sprendè kalinamų asmenų likimąa skyrè mirties arba 5, 8 ar 10 metų laisvės atėmimo bausmes.

\subsection{Grupinės bylos lageriuose}

Karo pradžioje SSRS NKVD nurodymu visoje Sovietų Sąungoje „imtasi aktyvių priemonių" kontrrevoliucinèms sukilèlių organizacijoms atskleisti ir sunaikinti. 1941-1944 m. beveik visuose lageriuose buvo „atskleistos“ 603 tokios organizacijos, suimta ir sušaudyta 4640 šių organizacijų narių. Visiems pateiktas vienodas kaltinimas - ginkluoto sukilimo rengimas, siekis užgrobus ginklus pereiti vokiškụjų fašistų pusèn. 1942 m. Usolsko lageryje išaiškinta „estų karinè-fašistinė sukilèlių orga-

\footnotetext{
83 Tekorius A., Sušaudytoji vyriausybè, Lietuvos žinios, 2012 rugsèjo 19 d., p. 10-11.

84 SSRS NKVD Ypatingasis pasitarimas - Sovietų Sąjungos neteisminė institucija, supaprastinta tvarka nagrinejusi baudžiamąsias bylas.

85 Burauskaitė T. B.,12-asis kilometras: 1942-1943 m. Sverdlovske sušaudyti Lietuvos piliečiai, Vilnius, 2015, p. 8.
} 
nizacija“, kuriai neva vadovavo buvęs Estijos gynybos ministras generolas Jaanas Sootsas, generalinio štabo viršininkas generolas Nikolajus Reekas, generalinio štabo pulkininkas Kurvicas. Pagal šią bylą buvo nuteisti 149 kaliniai. 1944 m. Norilsko lageryje išaiškinta „latvių sukilèlių organizacija“, kuriai neva vadovavo Latvijos kariuomenès pulkininkai V. Rožinskis, J. Aboltinšas, N. Plassas ir A. Plataisas. Pagal šią bylą nuteista 13 kalinių. 1943 m. Šiaurès Uralo lageryje likviduota „rumunų „Geležinès gvardijos“ sukilèlių organizacija“, pagal bylą nuteistas 31 kalinys ${ }^{86}$. Peršasi išvada, kad taip rastas paprastas būdas sunaikinti sovietų valdžiai pavojingą okupuotų valstybių politinị ir karinị elitą.

Panašaus likimo neišvengè ir lietuviai, kalinti Sevurallago Gario lageryje. $1942 \mathrm{~m}$. sausio mèn. buvo „atskleista“ šiame lageryje veikusi kontrrevoliucinė organizacija „Lietuvių gelbejjimo komitetas“. Enkavėdistai suèmè buvusi finansų ministrą ats. div. gen. Joną Sutkų, krašto apsaugos ministrą ats. plk. ltn. Juozą Papečki, vidaus reikalų ministrą Antaną Endziulaitị, užsienio reikalų ministrą Valdemarą Vytautą Čarneckį, ats. plk. ltn. Jurgị Kubilių, ats. mjr. Igną Slabšį, ats. kpt. Aleksandrą Ignatavičių ir dar 8 šiame lageryje kalejusius lietuvius. Juos Sverdlovsko srities NKVD valdyboje tarde Latvijos ir Lietuvos enkavèdistai. Tardytojams kankinant pavyko palaužti tardomuosius ir išgauti iš jų norimus prisipažinimus $^{87}$.

Iškentęs kankinimus kaltu neprisipažino tik ats. plk. ltn. Juozas Papečkys. Tardytojas Suchovas nutarime skirti J. Papečkiui 7 paras karcerio rašè: „Viso tardymo metu Papečkys elgiasi iššaukiančiai, šmeižia tardymo organus ir skatina kaltinamuosius atsisakyti savo parodymų. $1942 \mathrm{~m}$. birželio $12 \mathrm{~d}$. po akistatos su kaltinamuoju <...> Papečkys pareiškè, kad tardymo organai kurpia išgalvotas bylas ir nori ji sunaikinti kaip lietuvị. Taip pat ịkalbinejo kaltinamąji < $<>$ atsisakyti savo parodymų.

Visi tardomieji buvo apkaltinti vykdę lageryje antisovietinę agitaciją, sukūrę nelegalią kontrrevoliucinę sukilèlių organizaciją - Lietuvių gelbejjimo komitetą, kuris vokiečių kariuomenei artejjant prie Uralo

\footnotetext{
86 Žygelis D., Tekorius A., Plk. ltn. Juozas Papečkys - Lietuvos karo teisès patriarchas, Kardas, 2014 m., Nr. 2 (462), p. 2-9.

87 Ten pat.

88 Žygelis D., Tekorius A., Plk. ltn. Juozas Papečkys - Lietuvos karo teisès patriarchas, Kardas, 2014 m., Nr. 2 (462), p. 2-9.
} 
turètų organizuoti lageryje ginkluotą sukilimą, nuginkluoti sargybą, pagrobti ginklus ir maisto atsargas, išlaisvinti kalinius ir pereiti $\mathfrak{i}$ vokiečių kariuomenès pusę ${ }^{89}$.

1942 m. spalio 17 d. SSRS NKVD Ypatingasis pasitarimas prièmé sprendimą visus juos sušaudyti.

Panaši byla buvo sudaryta ir lietuviams, kalintiems Rešotų lageryje.

\subsection{Mirties bausmès vykdymas, laidojimas ir informacijos apie sušaudytuosius slèpimas}

Nuosprendžiai dažniausiai buvo vykdomi NKVD vidaus kalejjimų arba kalejimų, kuriuose kaliniai buvo tardomi ir kalinami, specialiai rūsiuose ịrengtose šaudymo kamerose. Kiekvienas nuteistasis buvo sušaudomas atskirai, šaunat iš pistoleto i pakauši.

Kraslago Rešotų lagerio kaliniai buvo tardomi Kansko kalejime, dauguma jų ten ir sušaudyti. Dalis Sol Ilecko (Čkalovo sr.) kalinių buvo sušaudyti Orenburge, dalis - pačiame Sol Ilecko kalejime. Sevurallago Gario lageryje kalinti nuteistieji buvo šaudomi Sverdlovsko srities NKVD valdybos vidaus kalejime.

Sušaudytųjų palaikai buvo sunkvežimiais išvežami už miesto ị NKVD priklausančias teritorijas ir užkasami masinèse kapavietėse, nesilaikant visuotinai priimtų laidojimo apeigų. Informacija apie mirties bausmès vykdymo procedūrą, vykdytojus ir aukų palaidojimo vietas buvo ịslaptinta ir griežtai saugoma.

Nors enkavèdistai įformindami tardymo procedūras, stengèsi sudaryti teisètumo regimybę, tačiau viešai pripažinti neteismine tvarka skirtų mirties nuosprendžių ir jų vykdymo nedrịso. Net pats mirties bausmès ịvykdymo faktas buvo slepiamas nuo sušaudytųjų artimųjų. Sovietų Sąjungos aukščiausių politinių institucijų nurodymu sušaudytųjų artimiesiems išduodamose pažymose buvo nurodoma melaginga informacija apie sušaudytojo mirties datą, vietą ir priežastị - neva mirè nuo infarkto, insulto, plaučių uždegimo ar kitos sunkios ligos. Artimieji neturejo galimybių aplankyti sušaudytojo palaidojimo vietos ir jo pagerbti. Suklastotas pažymas sušaudytųjų artimieji Lietuvoje gaudavo iki pat $1990 \mathrm{~m}$.

89 Ten pat. 
Iš viso buvo sušaudyta ne mažiau kaip 500 Lietuvos piliečių - daugiausia įvairaus rango valstybės institucijų tarnautojų, karių, policijos pareigūnų, mokytojų ${ }^{90}$.

Maskvos Butyrkų kalèjime buvo sušaudyti buvę vidaus reikalų ministrai ats. brg. gen. Julius Čaplikas ir ats. brg. gen. Kazys Skučas, gen. št. plk. Kostas Dulksnys, plk. ltn. Juozas Matusaitis, plk. ltn. Petras Kirlys; Maskvos Lefortovo kalejjime - brg. gen. Antanas Gustaitis; Sol Ilecko kalejjime Čkalovo srityje - ats. gen. ltn. Kazys Ladiga, ats. ltn. Evaristas Deniušis; Sverdlovsko kalejjime - buvęs finansų ministras ats. div. gen. Jonas Sutkus, buvęs krašto apsaugos ministras ats. plk. ltn. Juozas Papečkys, ats. plk. Viktoras Engleris, ats. plk. Juras Kubilius, plk. Adolfas Lapšys, plk. Julius Matulevičius, ats. gen. št. plk. ltn. Juozas Bačkus, plk. ltn. Antanas Urbelis, ats. plk. ltn. Jonas Gaudèšis, ats. kpt. Povilas Beleckas, ats. kpt. Aleksandras Ignatavičius, ats. kpt. Antanas Petruškevičius, ats. mjr. Ignas Slabšys, ats. ltn. Vytautas Pliuškevičius, ats. ltn. Povilas Žaltauskas, ats. j. ltn. Jurgis Kregždè, ats. j. ltn. Valerijonas BagdonasBagdonavičius, ats. j. ltn. Kazys Gasiūnas, ats. j. ltn. Liudas Kalnietis, ats. j. ltn. Juozas Barysas, ats. j. ltn. Aleksandras Ralčenis, ats. j. ltn. Antanas Verbyla, ats. j. ltn. Vincas Vileišis, ats. j. ltn. Kazys Stasys Adomulis, ats. j. ltn. Petras Kanauka; Kansko kalejime Krasnojarsko krašte - plk. Vincas Giriūnas, plk. ltn. Viktoras Kazlauskas, mjr. Vincas Ambrazevičius, mjr. Kazys Petkevičius, mjr. Vladas Rozmanas, kpt. Teodoras Balnas, kpt. Alfredas Garmus; Gorkio kalejime - plk. inž. Domas Grabys, mjr. Vytautas Bulvičius, kpt. Juozas Kilius, vyr. ltn. Dmitrijus Katasiūnas; Norilske Krasnojarsko krašte - gen. št. plk. Antanas Sidabras; Taišeto lageryje Irkutsko srityje - kpt. Andrius Draugelis.

Kalejimuose ir lageriuose ịkalinti žmonès buvo sparčiai naikinami ir kitaip - mirdavo nuo kankinimų, sunkių gyvenimo sąlygų, bado, šalčio, nepakeliamo darbo ir ligų.

Neatlaikęs nežmoniškų kalinimo sąlygų Maskvos Butyrkų kalèjime mire buvęs krašto apsaugos ministras, ministras pirmininkas Augustinas Voldemaras, po ilgo kalinimo Vladimiro ir kituose kalèjimuose Malenkų invalidų namuose Vladimiro srityje - buvęs krašto apsaugos ministras, ministras pirmininkas ats. plk. ltn. Antanas Merkys, Vilniaus Lukiškių

90 Burauskaitè T. B.,12-asis kilometras: 1942-1943 m. Sverdlovske sušaudyti Lietuvos piliečiai, Vilnius, 2015, p. 2. 
kalëjime - ats. gen. Pranas Liatukas, Gorkio kalèjime - buvęs žemès ūkio ministras ats. Itn. Stasys Putvis, Taišeto lageryje Irkutsko srityje div. gen. Zenonas Gerulaitis, Abezès lageryje Komijos ASSR - brg. gen. Jonas Juodišius, Čunos lageryje Irkutsko srityje - brg. gen. Juozas Barzda Bradauskas, Petropavlovsko lageryje Kazachstano SSR - plk. Leonas Gustaitis, Bratsko lageryje Irkutsko srityje - plk. Kazys Abaras, Lamos lageryje Krasnojarsko krašte - plk. Leonas Rupšys, plk. Alfonsas Sklèrius, mjr. Antanas Dapkus, plk. ltn. Petras Daukšys, mjr. Balys Steikūnas; Norilsko lageryje Krasnojarsko krašte - kpt. Liudas Liderskis, ltn. Liudas Urniežius, j. ltn. Petras Jakutis ir daugelis kitų.

Po kalinimo Mordovijos lageriuose tremtyje Murtos gyvenvieteje Krasnojarsko krašte mirè brg. gen. Kazys Sprangauskas, tremtyje Altajaus krašte - ats. gen. ltn. Vytautas Stomma ir kiti.

Negalutiniais duomenimis, nuo nepakeliamų kalinimo sąlygų kalejjimuose ir lageriuose mire daugiau kaip 2500 Lietuvos piliečių.

Likę gyvi, išgyvenę kalinimą ir tremtị, grịžę i Lietuvą, Lietuvos kariuomenès karininkai tebebuvo sovietų valdžios persekiojami - jiems buvo trukdoma įsidarbinti, prisiregistruoti, gyventi norimoje vietoje. Jie visą sovietmetį turejo kalinio, sovietams nepatikimo asmens žymę, buvo sovietinio saugumo institucijų stebimi ir kontroliuojami.

\section{LIETUVOS KARININKŲ PRIVERSTINE் EMIGRACIJA I VAKARUS}

Sovietų represijos privertè keliasdešimt tūkstančių lietuvių palikti Tèvynę, juos išblaškè po visą pasauli. Jie atsidūrẻ Vokietijoje, Austrijoje, Italijoje, Anglijoje, Jungtinėse Amerikos Valstijose, Kanadoje, Argentinoje, Brazilijoje, Australijoje ir kitose šalyse.

Pirmieji i Vakarus pasitraukẻ karininkai, lydèję ị Vokietiją pasitraukiantį Respublikos prezidentą Antaną Smetoną, - krašto pasaugos ministras brg. gen. Kazys Musteikis, plk. Juozas Musteikis, gen. št. plk. Aloyzas Valušis, prezidento asmeninis adjutantas gen. št. plk. ltn. Stepas Žukaitis.

Supratę realią sovietų keliamą grèsmę, į Vokietiją pasitraukè ir Valstybés saugumo departamento pareigūnai. $1940 \mathrm{~m}$. birželio $16 \mathrm{~d}$. Vokietijos sieną peržengè 15 VSD valdininkų, o liepos pabaigoje Vokietijoje jų jau 
buvo apie $30^{91}$.

1940 m. vasarą i Vokietiją pasitraukę politikai, valdininkai ir karininkai sudarè pirmąją pasitraukimo nuo sovietinės okupacijos bangą.

Vèliau i Vakarus pasitraukè ir daugiau karininkų, tarp jų - buvęs Lietuvos kariuomenès vadas, krašto apsaugos ministras div. gen. Stasys Raštikis. 1941 m. kovo mèn. bandantis pereiti Lietuvos-Vokietijos sieną sovietų pasieniečių sulaikytas buvęs karo aviacijos viršininkas brg. gen. Antanas Gustaitis 1941 m. spalio 16 d. buvo sušaudytas Maskvos Butyrkų kalejjime.

Kelios dešimtys Lietuvos kariuomenès karininkų 1940-1941 m. pasinaudojo repatriacijos i Vokietiją proceso galimybe. Jis buvo vykdomas pagal Molotovo-Ribentropo $1939 \mathrm{~m}$. rugsejo $28 \mathrm{~d}$. Maskvoje pasirašytą slaptajji protokolą, kuriame sakoma, kad „Sovietų Sąungos vyriausybė nedarys jokių kliūčių Reicho piliečiams ir kitiems vokiečių kilmès asmenims, gyvenantiems Sovietų įtakos sferoje ir norintiems išsikelti i Vokietiją arba $\mathfrak{i}$ Vokietijos įtakos sferą ${ }^{\text {“92 }}$. Lietuviai, nenorèdami tarnauti okupacineje Raudonojoje armijoje ar siekdami išvengti arešto, stengèsi įrodyti turintys teisę repatrijuoti. Kariai, padavę pareiškimus repatrijuoti ir pateikę dokumentus, patvirtinančius tokią teisę, buvo išleidžiami i atsargą ir turejjo galimybę išvykti ị Vokietiją ${ }^{93}$.

Dèl repatriacijos iš Raudonosios armijos 29-ojo šalių teritorinio korpuso 184-osios divizijos buvo atleisti 66 asmenys, tarp jų - 17 karininkų. Panaši padètis buvo ir 179-ojoje šaulių divizijoje, taip pat korpuso štabui pavaldžiose dalyse ir daliniuose. Suteikiant leidimą repatrijuoti kartu buvo atsikratoma nepatikimaisiais ${ }^{94}$.

Antrasis, didysis, pasitraukimas ị Vakarus vyko 1944 m. vasarą, Raudonajai armijai artėjant prie Lietuvos. Norėdami išvengti sovietinių represijų, apsaugoti šeimas, $\mathfrak{i}$ užsienio šalis pasitraukè tūkstančiai Lietuvos gyventojų, tarp jų - šimtai Lietuvos kariuomenès karininkų. Bendrais skaičiavimais, ị užsienio valstybes pasitraukè per 2000 Lietuvos kariuo-

\footnotetext{
91 Vaitiekus S., Lietuvos žvalgyba XX a. viduryje ir antroje puseje. Pirma knyga. In memoriam Lietuvos žvalgybos ir saugumo pareigūnams, Vilnius, 2017, p. 68-70.

92 Knezys S., Lietuvos kariuomenès naikinimas (1940 m. birželio 15 d.-1941 m.), Genocidas ir rezistencija, 2004.

93 Ten pat.

94 Ten pat.
} 
menės karininkų. Vien tik Vokietijoje 263 perkeltųų asmenų stovyklose 1946 m. gyveno 57495 lietuviai, tarp jų - 548 Lietuvos kariuomenės karininkai ir 121 atsargos karininkas ${ }^{95}$.

1948-1949 m. iš Vokietijos ir Austrijos ị JAV emigravo apie 30 000, Angliją - apie 4 500, Kanadą - apie 700 lietuvių, kartu dauguma karininkų, iki to gyvenusių Vokietijoje ${ }^{96}$.

I Vakarus buvo priversti pasitraukti 10 Lietuvos kariuomenès generolų: buvęs Lietuvos kariuomenès vadas, krašto apsaugos ministras div. gen. Stasys Raštikis, buvęs krašto apsaugos ministras brg. gen. prof. Stasys Dirmantas, buvęs krašto apsaugos ministras, Kariuomenès vyriausiojo štabo viršininkas brg. gen. Teodoras Daukantas, buvęs Kariuomenès vyriausiojo štabo viršininkas, Vietinès rinktinès vadas gen. Itn. Povilas Plechavičius, buvęs Kariuomenès vyriausiojo štabo viršininkas, kariuomenės vadas, pirmasis generalinis tarejjas vokiečių okupacijos metais gen. ltn. Petras Kubiliūnas, buvęs 3-iosios pėstininkų divizijos vadas div. gen. Mikas Reklaitis, buvęs kariuomenès kavalerijos viršininkas brg. gen. Kazys Tallat-Kelpša, buvęs kariuomenès intendantas brg. gen. Kazimieras Navakas, buvęs karo technikos viršininkas brg. gen. Klemensas Popeliučka, buvęs Kariuomenès teismo prokuroras brg. gen. Emilis Vimeris ${ }^{97}$.

Vokietijoje po karo kurị laiką gyveno 28 Lietuvos kariuomenès pulkininkai ir pulkininkai leitenantai: buvęs krašto apsaugos ministras plk. ltn. Balys Sližys, buvęs Laikinosios vyriausybès (1941 m.) vidaus reikalų ministras plk. Jonas Šlepetys, buvęs 2-ojo pėstininkų Didžiojo Lietuvos kunigaikščio Algirdo pulko vadas plk. Juozas Tumas (ištrūkęs iš Červenès žudynių), buvęs 2-ojo pèstininkų pulko vadas plk. Jonas Laurinaitis, buvęs 3-iojo dragūnų pulko vadas gen. št. plk. Antanas Rėklaitis, buvęs 8-ojo pėstininkų Kunigaikščio Vaidoto pulko vadas plk. Andrius Butkūnas-Butkus, buvęs 1-ojo husarų Didžiojo Lietuvos etmono Jonušo Radvilos pulko vado pavaduotojas plk. ltn. Juozas Ugianskis, buvęs karo aviacijos komendantas plk. Antanas Motuzas, buvęs Karo aviacijos mo-

\footnotetext{
95 Markūnas A., Lietuvos kariuomenès karininkai priverstinejje emigracijoje Vokietijoje 1944-1949 m., Kaunas, 2008, p. 6-34.

96 Ten pat.

97 Markūnas A., Lietuvos kariuomenès karininkai priverstinejje emigracijoje Vokietijoje 1944-1949 m., Kaunas, 2008, p. 6-34.
} 
kyklos viršininkas plk. ltn. Viktoras Reimontas, jūrų kpt. Antanas Kaškelis, buvęs Lietuvos šaulių sąjungos vadas plk. Pranas Saladžius, buvęs Kauno miesto ir apskrities komendantas plk. Jurgis Bobelis, buvęs karo sanitarijos viršininko padejejjas plk. Vladas Ingelevičius, buvęs 1-osios pèstininkų divizijos sanitarijos viršininkas plk. ltn. Julius Abraitis, buvęs prezidento A. Smetonos gydytojas plk. Baltrus Atkočiūnas, buvęs Ginklavimosi valdybos Gamybos skyriaus viršininkas plk. inž. Stasys Birutis, plk. Mykolas Kalmantas, buvęs Karo technikos štabo viršininkas plk. Petras Kutka, buvęs Vyriausiojo kariuomenès štabo Spaudos ir švietimo skyriaus viršininkas plk. ltn. Martynas Jonas Laurinaitis, buvęs Kėdainių apskrities karo komendantas plk. ltn. Motiejus Karaša ir kiti ${ }^{98}$.

Būdami emigracijoje, daugelis Lietuvos karininkų aktyviai dalyvavo išeivijos organizacijų politinèje ir kultūrinèje veikloje, rūpinosi „Lietuvos byla“.

Pasitraukę i Vakarus Lietuvos kariuomenès karininkai visada domino sovietines žvalgybos ir saugumo institucijas. Buvo stebima jų buvimo vieta, kontroliuojamas susirašinejjimas su artimaisiais, likusiais Lietuvoje. Juos ịvairiais būdais bandyta parvilioti ị Sovietų Sąjungą, nesutinkančius - pagrobti ar nužudyti.

Sovietinès kontržvalgybos ir Lietuvos SSR NKGB operatyvinès grupès Berlyne pastangomis $1945 \mathrm{~m}$. gruodị iš anglų okupacinės zonos buvo pagrobtas ir ị Maskvą atgabentas ats. gen. ltn. Petras Kubiliūnas - buvęs Lietuvos kariuomenès Vyriausiojo štabo viršininkas, pirmasis generalinis tarejjas vokiečių okupacijos metais. Jis sušaudytas Maskvoje 1946 m. rugpjūčio $22 \mathrm{~d} .{ }^{99}$

Nuo 1946 m. vasaros Lietuvių pabėgèlių stovyklose Vokietijoje pradèjo lankytis sovietinès repatriacijos komisijos, agituodamos pabėgèlius grịžti namo. Kartu atvykdavo ir NKGB-MGB ${ }^{100}$ operatyvinių grupių nariai, siekiantys kuo daugiau buvusių Lietuvos karininkų ir kitų aukštų pareigūnų susigrąžinti ị Lietuvą. Žinoma atvejų, kai NKGB-MGB operatyvinių grupių nariai naudojo psichotropines medžiagas ir alkoholị, $\mathfrak{i}$ pagalbą pasitelkdavo užverbuotus buvusius Lietuvos kariuomenès kari-

\footnotetext{
98 Ten pat.

99 Jankauskas V., Nepriklausomos Lietuvos generolai, I dalis, Vilnius, 1998, p. 182.

${ }^{100}$ MGB (rus. Министерство государственной безопасности - Valstybès saugumo ministerija) - Sovietų Sąungos valstybès saugumo institucija.
} 
ninkus ${ }^{101}$.

Bent du kartus bandyta pagrobti ats. gen. ltn. Povilą Plechavičių. Pas ji kelis kartus lankèsi sovietų saugumo agentas Juozas Mikuckis, buvęs Kauno komendantas. Jis su pagalbininkais stengèsi generolą P. Plechavičių nugirdyti ir slapta išvežti iš Vokietijos. Tačiau jų pastangos buvo bevaisès ${ }^{102}$.

Bandyta ịkalbèti grị̌ži ị Lietuvą ir div. gen. Stasị Raštikị. Pas jị 1947 m. sovietų saugumo buvo atsiųstas Vyčio Kryžiaus kavalierius, ats. plk. Pranas Tvaronas. Jis atsivežè Justo Paleckio ir div. gen. Vinco Vitkausko pasirašytus laiškus, kuriuose buvo siūloma „darbuotis sovietinės Lietuvos labui“"103. Yra duomenų, kad generolui su pasiūlymais nesutikus, ji bandyta nužudyti. 1948 m. Kaselio pabėgèlių stovykloje buvo suimtas MGB agentas Simas Pečiulionis, turèjęs užduotị nužudyti gen. Stasị Raštikį ${ }^{104}$.

Pabėgèlių stovykloje taip pat ieškota Kauno miesto ir apskrities komendanto plk. Jurgio Bobelio ir kitų karininkų.

\section{8. ŽUVUSIŲJŲ ATMINIMO İAMŽINIMAS}

Visi kovose su okupantais žuvę ir sovietines represijas patyrę Lietuvos kariuomenės karininkai - sušaudyti okupantų, žuvę kalèjimuose ir lageriuose ar mirę tremtyje - verti visokeriopos pagarbos ir jų atminimo j̇amžinimo. Daugelio karininkų kalinimo, žūties, gimimo ar gyvenimo vietose yra atidengtos memorialinès lentos, jų atminimui pastatyti paminklai.

2017 m. lapkričio 18 d. Kauno Aukštųjų Šančių karių kapinėse įamžintas Lietuvos karininkų - sovietinès ir nacistinès okupacijų aukų - atminimas. Atidengtas jiems skirtas paminklas, penkiose stelose iškaltos

813 žuvusių karininkų pavardès. Taip pagerbta 661 sovietinių repre-

\footnotetext{
${ }^{101}$ Markūnas A., Lietuvos kariuomenès karininkai priverstinèje emigracijoje Vokietijoje 1944-1949 m., Kaunas, 2008, p. 4.

102 Markūnas A., Lietuvos kariuomenès karininkai priverstinejje emigracijoje Vokietijoje 1944-1949 m., Kaunas, 2008, p. 5.

103 Ten pat.

104 Ten pat.
} 
sijų auka - 5 generolai, 7 atsargos generolai, 20 pulkininkų, 9 atsargos pulkininkai, 30 pulkininkų leitenantų, 11 atsargos pulkininkų leitenantų, 26 majorai, 27 atsargos majorai, 62 kapitonai, 43 atsargos kapitonai, 73 leitenantai, 120 atsargos leitenantų, 52 jaunesnieji leitenantai ir 176 atsargos leitenantai.

Svariausias rašytinis paminklas Lietuvos kariuomenès karininkams dešimties tomų enciklopedinis leidinys „Lietuvos kariuomenès karininkai 1918-1953“, parengtas didelio autorių ir talkininkų kolektyvo, išleistas Lietuvos karių, nukentejusių nuo sovietinio ir nacistinio genocido, artimųjų sąungos. Jame pateikti daugiau nei 7000 Lietuvos kariuomenès karininkų biografiniai duomenys, nuotraukos, aprašytos jų gyvenimo ir žūties aplinkybès.

\section{IŠVADOS}

1. Sovietines represijas patyrè šimtai Lietuvos kariuomenès karininkų. Dešimtys jų buvo nužudyti ar žuvo kalinimo ir tremties vietose. Tokị pat represijų mastą patyrè visų Sovietų Sąjungos okupuotų ir aneksuotų Baltijos šalių karininkai ir jų šeimos.

2. Karininkai buvo represuojami kaip keliantys realią grèsmę okupaciniam režimui. Jie buvo išsilavinę, gerai parengti ir organizuoti, lojalūs savo šaliai, turejjo autoritetą visuomenèje. Juos stengtasi pašalinti iš visuomenès nužudant ar ilgam izoliuojant kalejjimuose ir lageriuose.

3. Okupuotų ir aneksuotų šalių piliečių traukimas baudžiamojon atsakomybèn pagal okupavusios valstybès ịstatymus už jų deramai vykdytą konstitucinę pareigą - ištikimai tarnauti savo valstybès labui, ginti kraštą nuo vidaus ir išorès priešų, užtikrinti valstybès interesus, už priklausymą legalioms politinėms ir visuomeninėms organizacijoms, jų žudymas, kankinimas, teisimas neužtikrinant tinkamos gynybos, kalinimas nežmoniškomis sąlygomis, turto konfiskavimas, šeimų trèmimas ị atšiaurias, dažnai negyvenamas vietoves, jų marinimas badu ir šalčiu yra neteisètas, pažeidžiantis visuotinai pripažintas tarptautines teisès normas.

4. Sovietinès represijos taikytos ir niekuo detiems Lietuvos karininkų artimiesiems. Buvo konfiskuojamas suimtų karininkų šeimų turtas, šeimos tremiamos ị atšiaurias Sovietų Sąjungos vietoves, kur turèjo išgyven- 
ti itin sunkiomis sąlygomis. Dauguma šeimų tremtyje patyrė skaudžias netektis - ten mirè jų mažamečiai vaikai, senyvi tèvai.

5. Net ir po kalinimo ar tremties grịžusiems i Lietuvą karininkams buvo kliudoma prisiregistruoti didžiuosiuose miestuose, įsidarbinti pagal turimą specialybę, o jų vaikams - studijuoti aukštosiose mokyklose norimas specialybes, vykti ị užsienị.

6. Lietuvos karininkai sovietinei valdžiai nekèlè pasitikèjimo visą sovietinès okupacijos laikotarpi. Jie buvo stebimi ir kontroliuojami, daromos ịvairios kliūtys jų gyvenime. Okupantų žvalgybos ir saugumo institucijoms talkino šimtai agentų ir kolaborantų tiek Lietuvoje, tiek kalinimo ir tremties vietose. Jie uoliai rinko informaciją apie Lietuvos karininkų veiklą, nuotaikas ir ryšius.

7. Be dèmesio nebuvo palikti ir ị Vakarus pasitraukę Lietuvos karininkai. Juos stengtasi ịvairiais būdais ịkalbèti grịžti ị Lietuvą, žadant tinkamą tarnybą ir geras gyvenimo sąlygas. Nepavykus ịkalbėti, būta atvejų, kai sovietų žvalgybos pareigūnai rengè užsienio valstybèse esančių Lietuvos karininkų pagrobimo ar nužudymo operacijas.

8. Sovietinè valdžia slèpẻ represijų mastą. Slèpè ir klastojo informaciją apie kalèjimuose ir lageriuose žuvusius represuotus Lietuvos piliečius - jų žūties aplinkybes, vietą ir laiką, palaidojimo, tiksliau, užkasimo vietą. Žuvusiųjų, kurie buvo užkasti bendruose kapuose kartu su tūkstančiais kitų sovietinio režimo aukų, palaikų vietos praktiškai neįmanoma nustatyti, jų tinkamai perlaidoti ir pagerbti.

\section{LITERATŪRA}

Anušauskas Arvydas, Teroras. 1940-1958 m., Vilnius, 2012.

Anušauskas Arvydas, Sovietinis genocidas ir jo padariniai, http://genocid.lt/GRTD/Tremtis/arvydas1.htm

Banevičius Algirdas, 111 Lietuvos valstybès 1918-1940 politikos veikejų. Enciklopedinis žinynas, Vilnius, 1991.

Burauskaitè Teresè Birutè, 12-asis kilometras: 1942-1943 m. Sverdlovske sušaudyti Lietuvos piliečiai, Vilnius, 2015.

Grigaliūnas-Glovackis Vincas. Generolo atsiminimai, II-III dalys, atsakingasis redaktorius Gintautas Surgailis, Vilnius, 2017. 
Petruitis Jonas, Kaip jie mus sušaude, Kaunas, 1943.

Jankauskas Vidmantas, Nepriklausomos Lietuvos generolai, I dalis, Vilnius, 1998, p. 182.

Knezys Stasys, Lietuvos kariuomenès naikinimas (1940 m. birželio 15 d.-1941 m.), Genocidas ir rezistencija, 2004, http://genocid.lt/GRTD/ Tremtis/stasys.htm

Lietuvos kariuomenès karininkai 1918-1953, I-X tomai, red. Vytautas Zabielskas, Vilnius, 2001-2018.

Lietuvos karininko Juozo Palukaičio atsiminimai. Norilsko konclageris / Memoirs of the Lithuanian Military Officer Juozas Palukaitis. Norilsk Concentration camp, Vilnius, 2013.

Lietuvos krašto apsaugos ministrai ir kariuomenès vadai, I-II tomai, ats. redaktorius ir sudarytojas Gintautas Surgailis, Vilnius, 2008.

Lukšas Aras, Lietuvos karininkai okupantų taikiklyje, Lietuvos žinios, 2016 rugpjūčio $5 \mathrm{~d}$.

Markūnas Algirdas, Lietuvos kariuomenès karininkai priverstinèje emigracijoje Vokietijoje 1944-1949 m., Kaunas, 2008.

Martinionis Antanas, Prievarta ir smurtu, Kaunas, 1998.

Rudokas Jonas, Prarastieji Lietuvos talentai, Vilnius, 2001, p. 362-373.

Stanaitis Simas, Likimo vingiai, Kaunas, 1992.

Sušaudytos ir nukankintos Lietuvos vyriausybès, http://genocid.lt/ centras/lt/3002/a/

Tekorius Andrius, Sušaudytoji vyriausybè, Lietuvos žinios, 2012 rugsejo 19 d., p. 10-11.

Vaitiekus Severinas, Lietuvos žvalgyba XX a. viduryje ir antroje puséje. Pirma knyga. In memoriam Lietuvos žvalgybos ir saugumo pareigūnams, Vilnius, 2017, p. 68-70.

Vaitkevičiūtè Valerija, Tarptautinių žodžių žodynas, Vilnius, 2004, p. 908.

Žygelis Dalius, Tekorius Andrius, Plk. ltn. Juozas Papečkys - Lietuvos karo teisès patriarchas, Kardas, 2014 m., Nr. 2 (462), p. 2-9.

Iteikta 2019 m. gruodžio 20 d. 


\title{
THE SOVIET REPRESSION AGAINST THE OFFICERS OF THE LITHUANIAN ARMED FORCES
}

\author{
Colonel (Ret) Andrius TEKORIUS, \\ General Jonas Žemaitis Military Academy of Lithuania
}

The article reveals the reasons, nature and extent of the Soviet repression against the officers of the Lithuanian Armed Forces and presents the data about the repressed ministers and officers of the Lithuanian National Defence System.

The majority of the Lithuanian residents suffered from the repression during the Soviet occupation. The Lithuanian officers did not escape it as well and even became one of the first targets of the Soviet occupants. They were destroyed and persecuted for being an educated, professional, patriotic, highly motivated and organized force capable of organizing the armed resistance against the Soviet occupation and annexation. The repressions sought to break a possible resistance by eliminating patriotic officers from the military and destroying physically, imprisoning or exiling them to the harshest regions of the Soviet Union. Lithuanian officers proved their determination to defend their homeland during the fights with the Bolsheviks for the independence of Lithuania and the Soviet occupants were well aware of that.

Hundreds of officers of the Lithuanian Armed Forces were arrested, imprisoned or exiled. Some of them were shot in shooting chambers, while others were tortured by interrogators to complete exhaustion or died from cold, starvation and diseases in prisons and concentration camps. The conditions the deportees lived in were not any easier, they also suffered from starvation and cold in the furthest regions of the Soviet Union and worked in forests and factories.

Together with the active service officers, the Soviets also repressed Lithuanian reserve officers and graduates of the Military School, i.e. active and patriotic civil servants, members of the political and public organizations, commanders of the Riflemen's Union and members of different resistance organizations. 
A total of 1262 Lithuanian officers were subjected to direct Soviet repression; 150 of them were shot, 663 died in prisons, concentration camps or in exile, while more than 2000 officers opted for forced emigration.

The families of the repressed officers suffered greatly as well. They were left without a source of livelihood, their property was confiscated and they were exiled to harsh and mostly uninhabited areas of Komi, Kazakhstan, Altai, Sakha (also known as Yakutia), etc. in Siberia. The majority of them died there from cold, diseases and starvation.

The officers who survived the imprisonment and exile were persecuted upon their return to Lithuania. They were prevented from employment, registration and living in a desired place. Throughout the Soviet period, the survivors were tagged as prisoners and unreliable persons; they were monitored and controlled. 